\title{
Prioritization of Semi-Arid Agricultural
}

\section{Watershed Using Morphometric and Principal Component Analysis, Remote Sensing, and GIS Techniques, the Zerqa River Watershed, Northern Jordan}

\author{
Yahya Farhan*, Ali Anbar, Nisrin Al-Shaikh, Rami Mousa \\ Department of Geography, University of Jordan, Amman, Jordan \\ Email: *wjetfan47962@gmail.com
}

How to cite this paper: Farhan, Y., Anbar, A., Al-Shaikh, N. and Mousa, R. (2017) Prioritization of Semi-Arid Agricultural Watershed Using Morphometric and Principal Component Analysis, Remote Sensing, and GIS Techniques, the Zerqa River Watershed, Northern Jordan. Agricultural Sciences, 8, 113-148.

http://dx.doi.org/10.4236/as.2017.81009

Received: November 11, 2016

Accepted: January 21, 2017

Published: January 24, 2017

Copyright $\odot 2017$ by authors and Scientific Research Publishing Inc. This work is licensed under the Creative Commons Attribution International License (CC BY 4.0).

http://creativecommons.org/licenses/by/4.0/

\begin{abstract}
Remote sensing and GIS techniques were employed for prioritization of the Zerqa River watershed. Forty-three $4^{\text {th }}$ order sub-watersheds were prioritized based on morphometric and Principal Component Analysis (PCA), in order to examine the effectiveness of morphometric parameters in watershed prioritization. A comparison has been carried out between the results achieved through applying the two methods of analysis (morphometric and PCA). Afterwards, suitable measures are proposed for soil and water conservation. Topo sheets and ASTER DEM have been employed to demarcate the 43 subwatersheds, to extract the drainage networks, and to compile the required thematic maps such as slope categories and elevation. LANDSAT 8 image (April-2015) is employed to generate land use/cover maps using ENVI (v 5.1) software. The soil map of the watershed has been digitized using Arc GIS software. Prioritization of the 43 sub-watersheds was performed using ten linear and shape parameters, and three parameters which are highly correlated with components 1 and 2 . Subsequently, different sub-watersheds were prioritized by ascribing ranks based on the calculated compound parameters $(\mathrm{Cp})$ using the two approaches. Comparison of the results revealed that prioritization of watersheds based on morphometric analysis is more consistent and serves for better decision making in conservation planning as compared with the PCA approach. The recommended soil conservation measures are prescribed in accordance with the specified priority, in order to avoid undesirable effects on land and environment. Sub-watersheds classified under high priority class are subjected to high erosion risk, thus, creating an urgent need for applying soil and water conservation measures. It is expected that decision
\end{abstract}


makers will pay sufficient attention to the present results/information, activate programs encouraging soil conservation, integrated watershed management, and will continue working on the afforestation of the government-owned sloping lands. Such a viable approach can be applied at different parts of the rainfed highland areas to minimize soil erosion loss, and to increase infiltration and soil moisture in the soil profile, thus, reducing the impact of recurrent droughts and the possibility of flooding hazards.

\section{Keywords}

Prioritization, Morphometric Analysis, Principal Component Analysis, Soil Conservation, Land Use/Cover, GIS

\section{Introduction}

Soil erosion by water is considered a major cause for land degradation in Jordan. Soil erosion is not a recent problem in the country. It was active prehistorically and historically in the rainfed highlands of the Levant region including Jordan. Geoarchaeological and geomorphological studies carried out on the acceleration and intensity of soil erosion in historical time, indicate that historical soil erosion, intense agriculture, and agricultural terraces, were predominant over the Levantine highlands since the Iron Age [1]. Data performed on the alluvial deposits of the W.Wala (Central Jordan) suggest that the destruction of vegetation cover caused high soil erosion rates since the Neolithic and Chalcolithic periods. Indicators of soil erosion and the existence of agricultural terraces, denote that the highlands of Jordan experienced severe soil erosion at least since the Nabatean period, 3000 years ago [2]. Such a conclusion was verified recently by Jebari et al. [3], where they stated that the Mejerda watershed of Tunisia has experienced intense historical soil erosion over the last 3000 years. The catchment has been exposed to successive agricultural systems which caused intensive exploitation of land resources, land use/land cover abuse, and soil degradation for a long period of time. Quantitative and qualitative studies have been implemented on soil erosion and conservation in Jordan since the 1960s. Mc Donald Partners and Hunting Technical Services LTD [4] estimated that top productive soil is eroded at a rate of 0.14 annually. Thus, in light of rapid population growth (2.8\% per year), future sustainable agriculture is seriously threatened by intense soil erosion. The rainfed agricultural region of Jordan has experienced severe widespread erosion including splash, rill, gully and sheet erosion, and landslide activity. The Central Water Authority [5] and Schick [6] reported the occurrence of a heavy rainfall storm on 11 March 1966, which affected Ras En Naqb highlands (Southern Jordan), where the average $4 \mathrm{hr}$ rainfall yielded an intensity of $16 \mathrm{~mm} \cdot \mathrm{h}^{-1}$. Similarly, in 1991/1992, the annual rainfall doubled in the country, resulting in excessive soil erosion, soil slumping, shallow and deep landslides, and mudflows. Sheet and gully erosion were extensive on both land units of side slopes and farming areas. Boundary gullies were recorded on the highlands, infill 
valleys, and the Ghor. Since the 1940s, Jordan was exposed to repetitive severe rainfall storms, with a maximum rainfall intensity range in $24 \mathrm{hr}$ between 100 $\mathrm{mm}$ and $150 \mathrm{~mm}$ [7] [8] [9], whereas, the $48 \mathrm{hr}$ maximum rainfall intensity ranges between $100 \mathrm{~m}$ and $180 \mathrm{~mm}$. However, the maximum daily intensity $\left(\mathrm{mm} \cdot \mathrm{hr}^{-1}\right)$ varies between 2 and $6.6 \mathrm{~mm} \cdot \mathrm{hr}^{-1}$ [9]. Such high rainfall intensities caused serious soil erosion loss and high sediment yield in wadis and rivers draining to the Jordan Rift. Harza [10] for example, estimated the total sediment inflow to King Talal Reservoir (KTR) at $1.7 \mathrm{Mm}^{3} \cdot \mathrm{yr}^{-1}$, while Lara [11] reported that the total sediment volume is at $3.84 \mathrm{Mm}^{3} \cdot \mathrm{yr}^{-1}$. Earlier, Al-Sheriadeh and Al-Hamdan [12] assessed the erosion risk over the Zerqa River watershed and proposed two types of conservation practices: terracing and plantation of trees. Erosion risk was classified as: (i) severe erosion risk by gullying and dominant in the western part of the watershed; (ii) high erosion risk by overland flow and rill erosion, affecting the north eastern part of the catchment; (iii) high gullying erosion risk in the middle, extending eastward; and (iv) low erosion risk by gullying and overland flow dominant in the northern and southern-central part of the watershed. Moreover, using the AGNPS erosion model, Al-Sheriadeh et al. [13] simulated the annual sediment yield at King Talal reservoir at $2.9 \mathrm{Mm}^{3} \cdot \mathrm{yr}^{-1}$. Also, Al-ansari and Knutsson [14] concluded that W. Alarab Dam (northern Jordan) will be filled with sediments within 38 years. The estimated soil erosion loss for W. Kufranja [15], and W. Kerak [16] catchments using the RUSLE model, indicate that continuous deterioration of top productive soil, and high soil erosion rates seriously endanger the future of constructed dams, and the proposed dams such as W. Kufranja Dam (northern Jordan), and W. Kerak Dam, southern Jordan [17] [18]. Furthermore, the predicted average annual sediment yield (using the SWAT model) for W.Wala for the period 2000-2007, and 2008-2020 was 140.78 tons/year, and 123.1 tons/year respectively [19]. Similarly, the predicted average annual sediment yield for W. Mujib was 341.887 tons/years for the period 2007-2020 [20]. The results obtained using AGNPS erosion model are considered a serious threat to W. Mujib and W. Wala reservoirs as a result of reducing the operational life of the reservoirs by decreasing their active storage.

In situ field measurements of soil erosion were carried out in different bioclimate regions of the country (i.e., sub-humid Mediterranean (Salt, W. Kufranja and Jerash), semiarid (Muwaqar area), and arid (Azraq area), using different methods/techniques, i.e., splash, sheet, and runoff erosion [21] [22]. Measuring instruments were installed on small plots of different environmental characteristics, i.e., farming practice, and the existence of conservation measures (i.e. tillage land, fallow land, terraced land, gradient, slope form, and aspect). The measured splash erosion at the Salt area (sub-humid Mediterranean) range from 3.24 to 21.42 ton $\cdot \mathrm{ha}^{-1} \cdot \mathrm{yr}^{-1}$ [23], and 8 to 10 ton $\cdot \mathrm{ha}^{-1} \cdot \mathrm{yr}^{-1}$ at the W. Kufranja area [24]. A maximum 12.7 ton $\cdot \mathrm{ha}^{-1} \cdot \mathrm{yr}^{-1}$, and a minimum 2.9 ton $\cdot \mathrm{ha}^{-1} \cdot \mathrm{yr}^{-1}$ were recorded for the Jerash area [25]. The measured splash erosion for the Muwaqar area (semi arid) varies from 2.59 to 16.3 ton $\cdot \mathrm{ha}^{-1} \cdot \mathrm{yr}^{-1}$ [26], and for the arid area, Al-Hamdan [27] achieved figures ranging from 2.8 to $7.39 \mathrm{ton} \cdot \mathrm{ha}^{-1} \cdot \mathrm{yr}^{-1}$. By contrast, the 
measured runoff erosion ranges from 0.581 to 2.382 ton $\cdot \mathrm{ha}^{-1} \cdot \mathrm{yr}^{-1}$ for the Salt area, 1.05 ton $\cdot \mathrm{ha}^{-1} \cdot \mathrm{yr}^{-1}$ for the Muwaqar area, and $0.14 \mathrm{ton} \cdot \mathrm{ha}^{-1} \cdot \mathrm{yr}^{-1}$ for Azraq arid area [23] [26] [27].

Field measurement of soil erosion using pegs and field splash cups was also conducted in the Shawbak-Wadi Musa (Petra area) in southern Jordan. Soil erosion rates based on pegs range from 0.873 and $1.24 \mathrm{~mm} \cdot \mathrm{yr}^{-1}$, while the measured splash erosion for the same plots varies from 1.39 to 30.15 to $\mathrm{ha}^{-1} \cdot \mathrm{yr}^{-1}$ [28]. During the 1960s, several qualitative investigations were conducted on soil erosion and conservation for W. Ziqlab, north Jordan [29], the southern highlands [30], W. Hasa, south Jordan [31], and soil conservation surveys were carried out for W. Shueib and W. Kufrein, central Jordan [32]. The final products of these surveys were restricted to mapping soil erosion features using air photos and fieldwork, slope categories (\%), and physical and chemical properties of soils including soil types distribution. A conventional land capability map for W. Ziqlab was compiled, and a map illustrating the location of proposed soil conservation structures was also supplemented. Continuous human interventions, including the expansion of agriculture on steep slopes and beyond the limit of rainfed agriculture, continuous over-grazing, woodland cutting, rapid urbanization, progressive land fragmentation, and agricultural intensification are the main contributing factors underlying soil degradation in the rainfed agricultural lands of Jordan.

In light of the predominant high soil erosion loss and sediment yield rates, specific sub-watersheds show potential areas for preferential conservation intervention, and must be prioritized immediately for soil and water conservation practices, so as to maintain future agricultural sustainability [33]. Quantitative analysis of drainage basin morphometry was employed recently as an efficient tool to prioritize sub-watersheds for soil and water conservation measures [34]-[45]. Erosion risk parameters represented by linear and shape morphometric variables must be calculated to prioritize watersheds for soil conservation. It has been postulated earlier that linear parameters retain a direct relationship with erodibility. Thus, the highest value of the linear variables was ranked 1 , the second highest value ranked 2 and so on. By contrast, the shape parameters have an inverse relation with linear parameters, consequently, the lower their values, the greater the erodibility [37] [38] [46] [47]. Subsequently, the lowest value of shape variable was rated as rank 1 and the second lowest as rank 2 and so on. Compound parameter $\left(C_{p}\right)$ was calculated by adding up all the ranks of linear variable, as well as shape variable, and then, dividing by the number of all parameters. Following the rating of every single morphometric parameter, the ranking values for all linear and shape parameters pertaining to each sub-watershed are added up for each of the sub-watershed to attain compound parameter $\left(C_{p}\right)$ scores based on the average value of these parameters. Moreover, the subwatershed having the lowest compound parameter score was assigned the highest priority, the next higher value was referred as second priority and so on [43]. Highest priority denotes the greater degree of soil erosion in that particular 
sub-watershed, thus, it is considered a potential area for applying soil conservation measures [48]. However, Patel et al. [38] stated that the prioritization concept is found to be very helpful for understanding the fluvial and morphological characteristics of individual watersheds or sub-watersheds, and for designing efficient soil conservation and water harvesting structures to control soil erosion, and conserve water over a watershed.

Recent investigations carried out on watershed prioritization, employ various methods of analysis, such as morphometric analysis combined with the sediment yield index (SYI) model, and sediment product rate (SPR) [49]. Others adopted the analysis of linear and shape morphometric parameters for prioritization [50]. In some other studies, morphometric analysis, land use/ land cover parameters, sediment yield index [42], and Snyder's synthetic unit hydrograph method have been incorporated in analysis [51]. In several other investigations, morphometric aspects associated with predicted annual soil loss parameter, based on the USLE or RUSLE models, or soil erosion susceptibility analysis were employed for identifying potential sub-watersheds for conservation works planning [52]. Others utilized morphometric indices and the Fuzzy Analytical Hierarchy, including the Saaty Analytical Hierarchy Process [53] for prioritizing watersheds for appropriate control measures. The present study focused on:

1. Prioritization of 43 sub-watersheds for soil conservation based on morphometric analysis using GIS and RS, and Principal Component Analysis (PCA),

2. Evaluate the final priority ranks for the 43 sub-watersheds based on morphometric analysis and PCA,

3. Compiling spatial maps illustrating the final priority ranks for the 43 subwatersheds, and

4. Propose suitable soil and water conservation measures for the Zerqa River watershed in northern Jordan.

Information pertaining to present land use/cover, slope, and soil type is employed to help in suggesting suitable soil conservation measures for different sub-watersheds of the Zerqa River. Further, the locations of proposed soil conservation structures were generally clarified. The results achieved are very important to conserve soil and water, and to provide significant information which can assist decision-makers in formulating more reliable soil and water conservation plans for the Zerqa River watershed in the future. GIS techniques have proven to be powerful tools for watershed prioritization, sustainable development and management of land resources. Morphometric analysis in this context is a key to understanding the hydro-morphological processes and characteristics of drainage networks. Linear and shape parameters can be measured and computed using DEM'S, Arc GIS software and the mathematical formulas developed for this purpose [54] [55] [56] [57] [58].

Prioritization studies demonstrated the role of the geographic information system (GIS), remote sensing (RS), and morphometric analysis as powerful tools in ranking different sub-watersheds according to the order in which they have to 
be taken for remedial measures through conservation operations [48]. Elaborations have been undertaken regarding the selection of rational morphometric parameters in relation to erodibility to prioritize sub-watersheds [46] [55] [56] [57] [58]. Five linear morphometric parameters (bifurcation ratio, drainage density $\left(\mathrm{km} / \mathrm{km}^{2}\right)$, texture ratio, length of overland flow $(\mathrm{km})$, and stream frequency), and five morphometric shape parameters (compactness coefficient, circularity ratio, elongation ratio, shape factor, and form factor) are often utilized and employed for watershed prioritization. The chosen parameters are reported to be the most consistent variables in prioritizing sub-watersheds for conservation practice.

\section{The Study Area}

Prioritization of the Zerqa River sub-watersheds in northern Jordan was conducted. The catchment covers an area of $4160 \mathrm{~km}^{2}$, and lies between the latitudes $35^{\circ} 32^{\prime} \mathrm{E}$ and $36^{\circ} 45^{\prime} \mathrm{E}$ and $31^{\circ} 51^{\prime} \mathrm{N}$ and $32^{\circ} 35^{\prime} \mathrm{N}$. The watershed extends from the western highlands and the Ghor to the eastern desert, beyond the JordanianSyrian border, and terminates at the piedmont of Jebel el Druz northeast (Figure 1). The catchment is drained by two major tributaries: W. Zerqa and W. Dhulil which drain the western and eastern parts of the watershed respectively. Both tributaries are joined at Sukhna town to form what is known as the "Zerqa River". The elevation of the catchment ranges from $-367 \mathrm{~m}$ (b.s.l) to $1589 \mathrm{~m}$ (a.s.l) (Figure 2).

Climato-morphogenetic processes are often controlled slope elements and slope segments [59] [60]. Slope units sequence at the Zerqa River is occasionally interrupted by landslide complexes and structural benches due to progressive rejuvenation in the western part, and successive basaltic flows in the eastern part of the catchment. A prominent slope variation exists across the watershed $\left(0^{\circ}\right.$ to $\left.20^{\circ}-45^{\circ}\right)$, but higher slope categories $\left(10^{\circ}-15^{\circ}, 15^{\circ}-20^{\circ}\right.$, and $\left.20^{\circ}-45^{\circ}\right)$ domi-

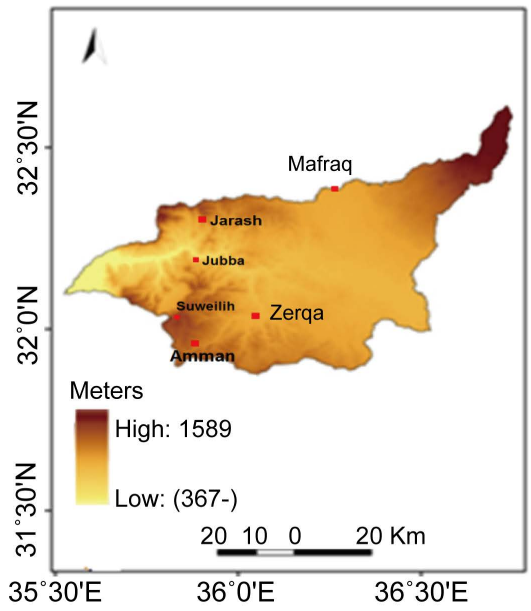

(a)

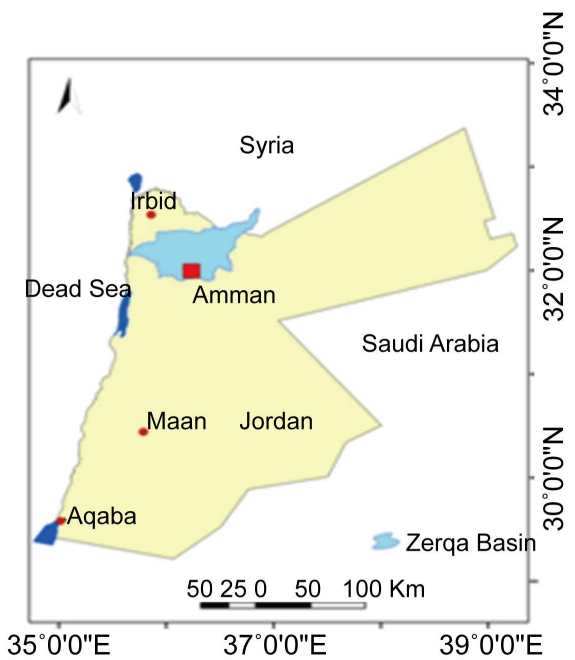

(b)

Figure 1. DEM (a) and location of the study area (b). 


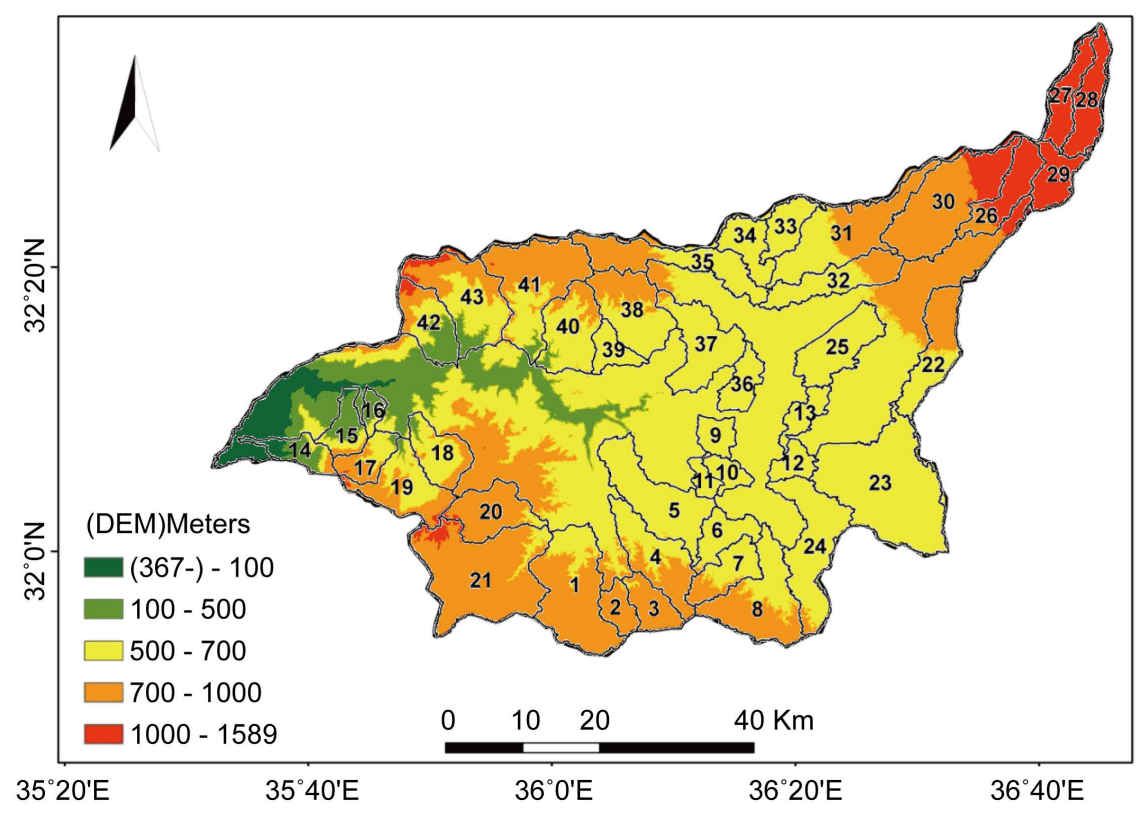

Figure 2. Digital Elevation Model and the 43 sub-watersheds of the Zerqa River.

nate the rejuvenated belt, whereas, slope categories of $0^{\circ}-5^{\circ}, 5^{\circ}-10^{\circ}$, and $10^{\circ}-$ $20^{\circ}$ characterize the eastern part of the catchment (Figure 3). The aspect of terrain units has a great impact on exposure to sun, precipitation patterns, wind, and thus evaporation rate and vegetation type and density. Terrain units facing north, northeast, southwest are predominant in the western part of the watershed. Therefore, a higher moisture content and lower evaporation rate dominate. Rainfed farming is practiced here, while irrigated agriculture is employed in the lower Zerqa River floodplain and at the upper arid part of the watershed. A sequence of rocks was exposed across the watershed, ranging in age from Triassic to resent sediments. The northeastern part of the watershed is covered by basalt rocks ranging in age from Oligocene to Pleistocene. Table 1 displays the lithological units and structure in the study area. The Zerqa Group (sandstones, dolomites and shales) is considered the older rock unit exposed in the catchment (Triassic/Jurassic). This rock unit is overlain by Kurnub sandstone of the Lower Cretaceous age. The sandstones are overlain by the Cenomanian-Turonian Group of Upper Cretaceous age, which consists of two lithological units: the Nodular limestone unit, or the Marl-Clay unit, and the Echinoidal limestone unit (the Limestone-Marl unit).

The massive Limestone unit overlies the Cenomanian-Turonian Group and consists of highly jointed and fractured thick limestone beds. The Chert-Limestone unit (from the Early Paleocene to Middle Eocene) is the last unit exposed, and is comprised of massive chalky limestone, thin bedded limestone and chert layers [61]-[66]. From early Miocene to historic time (4000 years old in Syria, and 760 years old in the Arabian Peninsula), six basaltic flows occurred and separated from each other by $5 \mathrm{~m}$ of fossil soils, red clay beds, and fossil weathered basalt surfaces [66]. The coarse and fine clastic materials washed down along the 


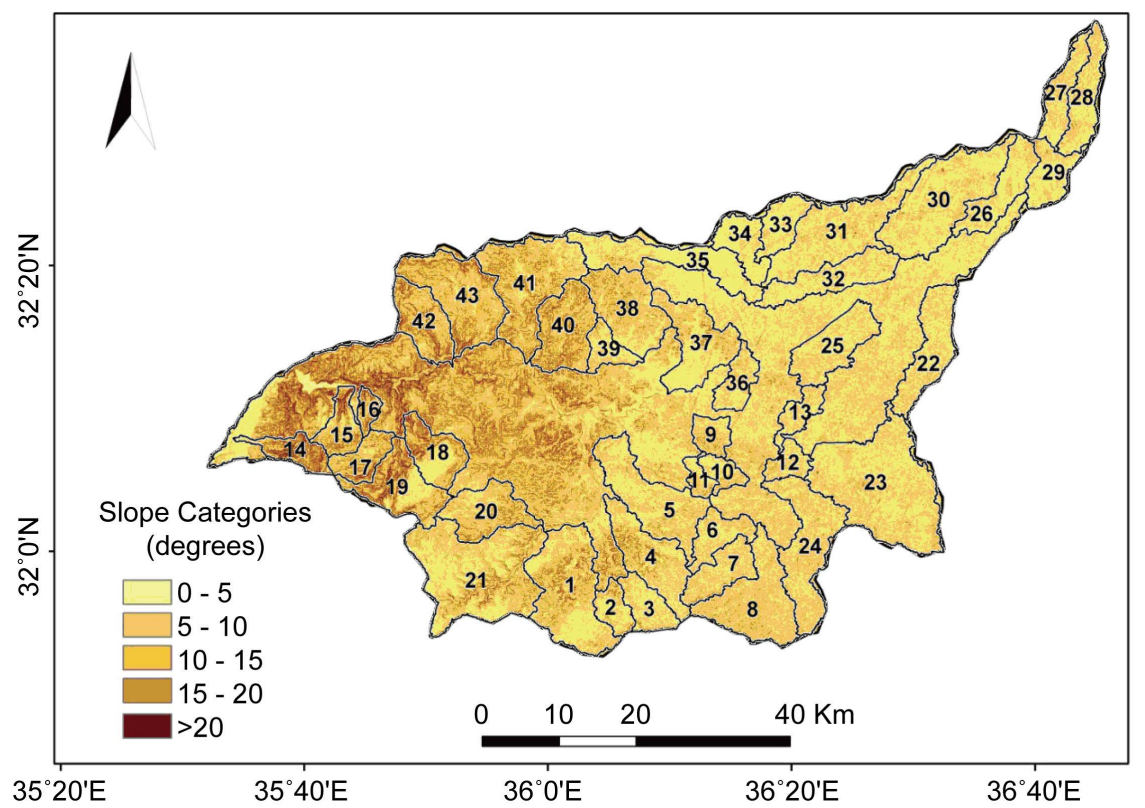

Figure 3. Slope categories of the study area.

Table 1. Lithological units exposed in the Zerqa River Watershed (Based on: 63-64).

\begin{tabular}{|c|c|c|c|c|}
\hline Period & Epoch & $\begin{array}{c}\text { Quennell } \\
\text { [65] }\end{array}$ & $\begin{array}{l}\text { Bender } \\
{[61][62]}\end{array}$ & $\begin{array}{l}\text { Thickness } \\
\text { (m) }\end{array}$ \\
\hline $\begin{array}{c}\text { Tertiary } \\
\text { and Quaternary }\end{array}$ & $\begin{array}{c}\text { Pleistocene } \\
\text { Holocene } \\
\text { Pliocene-Eocene }\end{array}$ & \multicolumn{3}{|c|}{$\begin{array}{l}\text { Basalts, unconsolidated sediments, mudflats, Lisan marl, } \\
\text { fluviatile gravel, and infill wadi. }\end{array}$} \\
\hline \multirow{4}{*}{$\begin{array}{c}\text { Upper } \\
\text { Cretaceous }\end{array}$} & $\begin{array}{l}\text { Santorian- } \\
\text { Coniacian }\end{array}$ & Belqa & $\begin{array}{l}\text { Chert-Limestone } \\
\text { Silicified Limestone }\end{array}$ & $\begin{array}{c}180 \\
20-100 \\
\text { (Not exposed) }\end{array}$ \\
\hline & Turonian & & Massive Limestone & $10-128$ \\
\hline & \multirow[t]{2}{*}{ Cenomanian } & Ajlune & Echinoidal Limestone & 300 \\
\hline & & & Nadular Limestone & 300 \\
\hline Lower Cretaceous & $\begin{array}{l}\text { Albian } \\
\text { Aptian }\end{array}$ & Kurnub & Vari-Coloured Sandstone & 330 \\
\hline Jurassic/Triassic & Neocomian & Zerqa & & 500 \\
\hline
\end{tabular}

slopes to wadi bottoms and depressions constitute the recent sediments. Its thickness approaches $50 \mathrm{~m}$ and the width is $500 \mathrm{~m}-600 \mathrm{~m}$ between Zerqa city and Sukhna town. West of King Talal Reservoir, the Zerqa River built a wide floodplain, bounded near its outlet by the badlands terrain unit or what is locally named the Katar. The badlands are composed of Lisan marl of Late Pleistocene. Three major compressional structures occupy the western part of the Zerqa River catchment. These are: W. Shueib structure, Biren structure, and the AmmanHallabat structure. Each of these consists of several highly folded anticlines, synclines, partially overturned to the west, and occasionally it is heavily deformed by jointing and faulting [67] [68]. The presence of old large landslide complexes at the front and the flanks of these structures, along with the presence of weak rocks with low shearing resistance indicate the role of tectonics, lithology and 
repetitive heavy rainstorms as controlling factors in their initiation and distribution. The old landslide complex close to the Zerqa River bridge, and the Bassa landslide west of King Talal Reservoir are the best examples. The lower slopes of landslide complexes are often active landslide zones due to river incision, lateral erosion, recent tectonic activity [69] and peak flooding. The old landslide complexes are tentatively from the Pliocene and Quaternary age [70].

The climate in the Suweileh and Jubba areas is sub-humid Mediterranean, then it shifts to semi-arid in the Baq'a depression and Jerash, whereas, arid conditions dominate the eastern part of the watershed. Generally, the climate is characterized by long, hot and dry summers, and relatively short and wet winters [71]. The average annual rainfall varies from $541 \mathrm{~mm}$ at Suweileh (1050 m a.s.l) to $365 \mathrm{~mm}$ at Jerash (550 $\mathrm{m}$ a.s.l), whereas, the annual rainfall recorded at Zerqa is $132 \mathrm{~mm}$ (510 m a.s.l), and $155 \mathrm{~mm}$ at Mafraq (695 m a.s.l) at the northern border of the watershed. Much rainfall particularly in January, February and March, is associated with heavy rainfall storms of high intensity; these may induce landslides and soil erosion loss. A heavy rainstorm that occurred on March $4^{\text {th }}, 1983$ initiated dozens of shallow landslides in the Suweileh-Jerash area. The average annual discharge of the watershed is 70.3 MCM at King Talal Reservoir. The slopes often have a poor vegetation cover, and lack conservation measures. Woods on bare slopes have been deforested in the past, and are severely overgrazed at present. Rainfed farming (i.e. cereals, fruit trees, and olive trees) dominates the western highlands of the catchment (Figure 4), of Vertisol and Lithic subgroups soil (Figure 5), but with poor conservation measures. Irrigated agriculture is practiced along the lower Zerqa River floodplain based on the King Talal Reservoir, the bottom and the alluvial fan of W. Jerash through utilizing available water from the base flow of springs between Jerash town and the Zerqa River bridge. Further, irrigated agriculture is practiced in the northern and east-

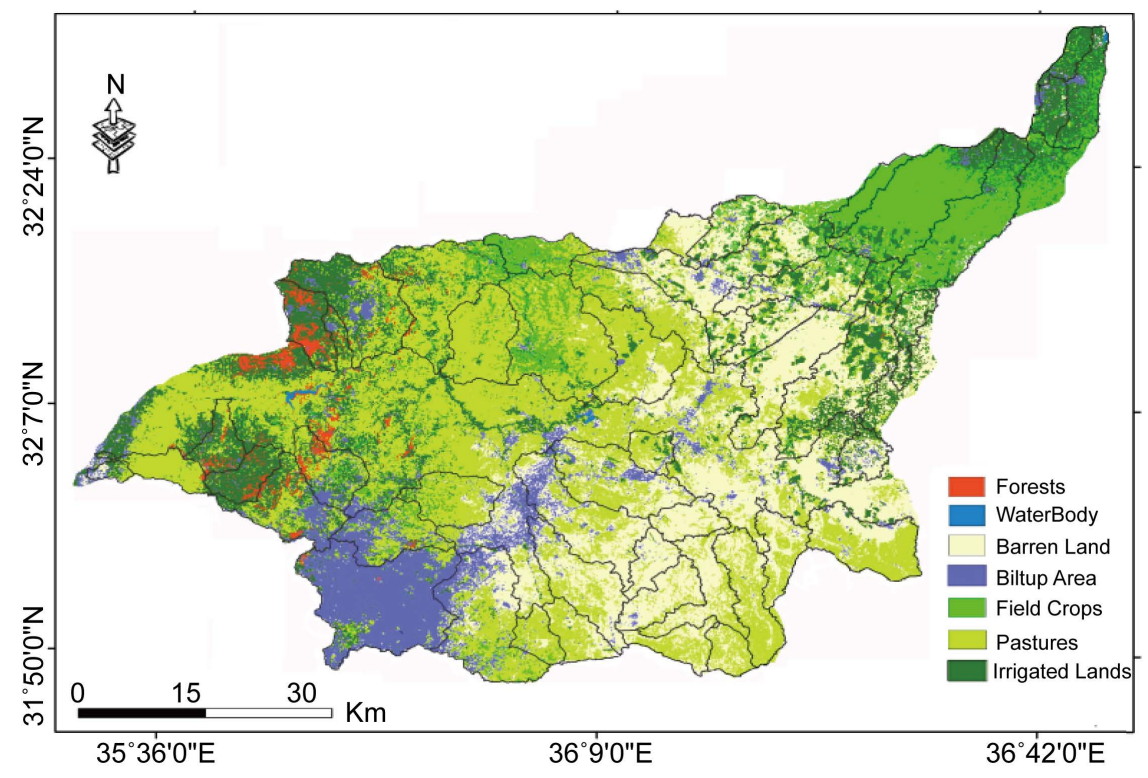

Figure 4. Land use/cover of the Zerqa River watershed. 




Figure 5. Soil types and the 43 sub-watersheds.

ern arid areas around Mafraq and Hallabat, where dozens of wells are installed, and groundwater is heavily exploited for this purpose. Pinus halepensis was planted in mid-1950s and 1960s to provide protective measures against soil erosion and landslide activity [72] around the Zerqa river bridge, Jerash area.

\section{Materials and Methodology}

Morphometric analysis for prioritization of the Zerqa River sub-watersheds was performed using topographic maps of scale 1:50,000 (20 m contour interval) obtained from the Royal Jordanian National Geographic Centre (RJNGC), Amman. Then, they were scanned, geo-referenced, and converted to zone $36 \mathrm{~N}$ projection system using Arc GIS 10.1 and the accompanying packages. The Zerqa River catchment and the 43 sub-watersheds were demarcated initially using topographic sheets. ASTER DEM (30 m spatial resolution) was employed to extract drainage networks of the Zerqa River watershed and the 43 fourth-order subwatersheds using the Arc Hydro tool. Stream order was assigned using the stream ordering system elaborated by [54] [55] [56] [57] [58]. The Zerqa River watershed was found to be of $7^{\text {th }}$ order. Five basic morphometric parameters such as: area $(A)$, basin length $\left(L_{b}\right)$, perimeter $(P)$, stream order $(u)$, and stream length $(\mathrm{L})$, were measured directly from the DEM using GIS software (Table 2). The five linear parameters which are considered in prioritization of watersheds based on morphometric analysis are: bifurcation ratio $\left(\mathrm{R}_{\mathrm{b}}\right)$, drainage density $\left(D_{d}\right)$, stream frequency $\left(F_{s}\right)$, texture ration $\left(T_{r}\right)$, and length of overland flow $\left(L_{o}\right)$. Further, the shape parameter utilized in this research are: form factor $\left(R_{f}\right)$, shape factor $\left(B_{s}\right)$, elongation ratio $\left(R_{e}\right)$, compactness coefficient $\left(C_{c}\right)$, and Circularity $\left(\mathrm{R}_{\mathrm{c}}\right)$. The linear and shape parameters are considered to be the two dimensional properties of a watershed. In this regard they constitute the areal elements of a 
Table 2. Computation of basic, linear and shape morphometric parameters.

\begin{tabular}{|c|c|c|}
\hline Morphometric Parameters & Formula & References \\
\hline \multicolumn{3}{|l|}{ Basic Parameters } \\
\hline Area of Basin (A) Perimeter of Basin (P) & $\begin{array}{l}\text { Plan area of the watershed }\left(\mathrm{km}^{2}\right) \\
\text { Perimeter of watershed }(\mathrm{km})\end{array}$ & $\begin{array}{l}{[54]} \\
{[54]}\end{array}$ \\
\hline $\begin{array}{l}\text { Stream order }(\mathrm{u}) \\
\text { Basin Length }\left(\mathrm{L}_{\mathrm{b}}\right) \\
\text { Stream Length }\left(\mathrm{L}_{\mathrm{u}}\right)\end{array}$ & $\begin{array}{l}\text { Hierarchical rank } \\
\text { Length of basin }(\mathrm{km}) / \mathrm{GIS} \text { software analysis } \\
\mathrm{L}_{\mathrm{b}}=1.321 \times \mathrm{A}^{0.568 \mathrm{a}} \\
\text { Length of the Stream }(\mathrm{km})\end{array}$ & $\begin{array}{l}{[54]} \\
{[55][56]} \\
{[46]} \\
{[54]}\end{array}$ \\
\hline \multicolumn{3}{|l|}{ Linear Parameters } \\
\hline Bifurcation ratio $\left(\mathrm{R}_{\mathrm{b}}\right)$ & $\begin{array}{l}\mathrm{Rb}=\mathrm{N}_{\mathrm{u}} / \mathrm{N}_{\mathrm{u}}+1 \text {, where } \\
\mathrm{N}_{\mathrm{u}}+1=\text { no. of segments of the next higher order }\end{array}$ & {$[54]$} \\
\hline $\begin{array}{l}\text { Drainage density }\left(D_{d}\right) \\
\left(\mathrm{km} / \mathrm{km}^{2}\right)\end{array}$ & $\begin{array}{l}\mathrm{D}_{\mathrm{d}}=\mathrm{L}_{\mathrm{u}} / \mathrm{A}, \text { Where } \\
\mathrm{Lu}_{\mathrm{u}}+\text { total stream length of all orders }(\mathrm{km}) \\
\mathrm{A}=\text { area of the watershed }\left(\mathrm{km}^{2}\right)\end{array}$ & [54] \\
\hline $\begin{array}{l}\text { Stream frequency }\left(\mathrm{F}_{\mathrm{u}}\right) \\
\left(\mathrm{no.} / \mathrm{km}^{2}\right)\end{array}$ & $\begin{array}{l}\mathrm{F}_{\mathrm{u}}=\mathrm{N}_{\mathrm{u}} / \mathrm{A}, \text { where } \\
\mathrm{N}_{\mathrm{u}}=\text { total no. of steams of all orders } \\
\mathrm{A}=\text { area of the basin }\left(\mathrm{km}^{2}\right)\end{array}$ & [54] \\
\hline $\begin{array}{l}\text { Texture ratio }(\mathrm{T}) \\
\left(\text { no. } / \mathrm{km}^{2}\right)\end{array}$ & $\begin{array}{l}T=N_{u} / P, \text { where } \\
N_{u}=\text { total no. of streams of all orders } \\
P=\text { perimeter }(\mathrm{km})\end{array}$ & [54] \\
\hline Length of overland flow $(\mathrm{km}) \mathrm{L}_{o}$ & $\begin{array}{l}\mathrm{L}_{\mathrm{o}}=1 / 2 \mathrm{D}_{\mathrm{d}}, \text { where } \\
\mathrm{D}_{\mathrm{d}}=\text { drainage density }\end{array}$ & [54] \\
\hline \multicolumn{3}{|l|}{ Shape parameters } \\
\hline Form factor $\left(\mathrm{R}_{\mathrm{f}}\right)$ & $\begin{array}{l}\mathrm{R}_{\mathrm{f}}=\mathrm{A} / \mathrm{L}_{\mathrm{b}}^{2}, \text { where } \\
\mathrm{A}=\text { area of the basin }\left(\mathrm{km}^{2}\right) \\
\mathrm{L}_{\mathrm{b}}=\text { basin length }(\mathrm{km})\end{array}$ & [54] \\
\hline Shape factor $\left(B_{s}\right)$ & $\begin{array}{l}\mathrm{B}_{\mathrm{s}}=\mathrm{L}_{\mathrm{b}}^{2} / \mathrm{A}, \text { where } \\
\mathrm{L}_{\mathrm{b}}=\text { basin length }(\mathrm{km}) \\
\mathrm{A}=\text { area of the basin }\left(\mathrm{km}^{2}\right)\end{array}$ & [46] \\
\hline Elongation ratio $\left(\mathrm{R}_{\mathrm{e}}\right)$ & $\begin{array}{l}\mathrm{Re}=1.128 \sqrt{\mathrm{A} / \mathrm{L}_{\mathrm{b}}}, \text { where } \\
\mathrm{A}=\text { area of the basin }\left(\mathrm{km}^{2}\right) \\
\mathrm{L}_{\mathrm{b}}=\text { basin length }(\mathrm{km})\end{array}$ & [58] \\
\hline Compactness coefficient $\left(\mathrm{C}_{c}\right)$ & $\begin{array}{l}C c=\frac{\mathrm{P}}{2 \sqrt{\pi \mathrm{A}}}, \text { where } \\
\mathrm{P}=\text { perimeter of the basin }(\mathrm{km}) \\
\mathrm{A}=\text { area of the basin }\left(\mathrm{km}^{2}\right)\end{array}$ & [54] \\
\hline Circularity ratio $\left(\mathrm{R}_{c}\right)$ & $\begin{array}{l}\mathrm{R}_{\mathrm{c}}=4 \times n \times \mathrm{A} / \mathrm{P}^{2}, \text { where } \mathrm{n}=3.14 \\
\mathrm{~A}=\text { area of the basin }\left(\mathrm{km}^{2}\right) \\
\mathrm{P}=\text { perimeter }(\mathrm{km})\end{array}$ & [57] \\
\hline
\end{tabular}

watershed, and it is very important for quantitative morphometric analysis of drainage basins. The linear and shape parameters for the 43 sub-watershed were derived and calculated using the DEM, GIS software, and the mathematical equations developed by [54] [55] [56] [57] [58] [46]. A land use/land cover map was compiled using ENVI version 5.1, LANDSAT 8 (April) 2015, and supervised classification. The Maximum Likelihood Method of classification technique was employed to classify land use/cover into categories, based on the classification system proposed by Anderson et al. [73]. A soil map was drawn from the 1994 National Soil Survey maps and reports pertaining to the national soils and land use maps [74]. Moreover, a slope map for the Zerqa River watershed was drawn 
using ASTER DEM as shown in Figure 3. The slope in the catchment varies from $0^{\circ}$ to $>25^{\circ}$ catgories. The map which illustrates the 43 sub-watersheds was superimposed on the DEM, slope categories, land use, and soil maps. Principal Component analysis (PCA) was employed to explore the most influential morphometric parameters for prioritization of watersheds based on the parameters which are highly correlated with important components. A comparison of the results of prioritization obtained based on applying the two methods of analysis was performed.

\section{Results and Discussion}

\subsection{Morphometric Analysis}

Geomorphometric analysis was conducted for the entire Zerqa River watershed and the 43 sub-watersheds to assess the characteristics and properties of the drainage networks. Fifteen morphometric parameters which represent basic, linear and shape parameters were utilized to prioritize sub-watersheds for soil conservation. Table 3 displays the computed morphometric parameters. The total drainage area of the watershed is $4895.11 \mathrm{~km}^{2}$, and the drainage pattern is dendritic to sub-dendritic in the upper catchment, and trellis type in the southern and western type. The watershed is classified as a seventh basin-order (Figure 6) with a length of $143.8 \mathrm{~km}$, and perimeter of $464.7 \mathrm{~km}$. The total number of streams $(\mathrm{Nu})$ is 5806 , and the first order streams account for $79.6 \%$ of the total number of streams in the catchment. Generally, the higher the order is, the longer the length of stream in nature. The total stream length $\left(\mathrm{L}_{\mathrm{u}}\right)$ of the catchment is $7148.25 \mathrm{~km}$, and the first order streams represent $48.5 \%$ of the total stream length. A variation exists in stream length ratio $\left(\mathrm{R}_{\mathrm{L}}\right)$ between the streams for different orders of the Zerqa River catchment (0.376 - 3.4), and the 43 subwatersheds. Such variation might be attributed to geomorphic changes in slope

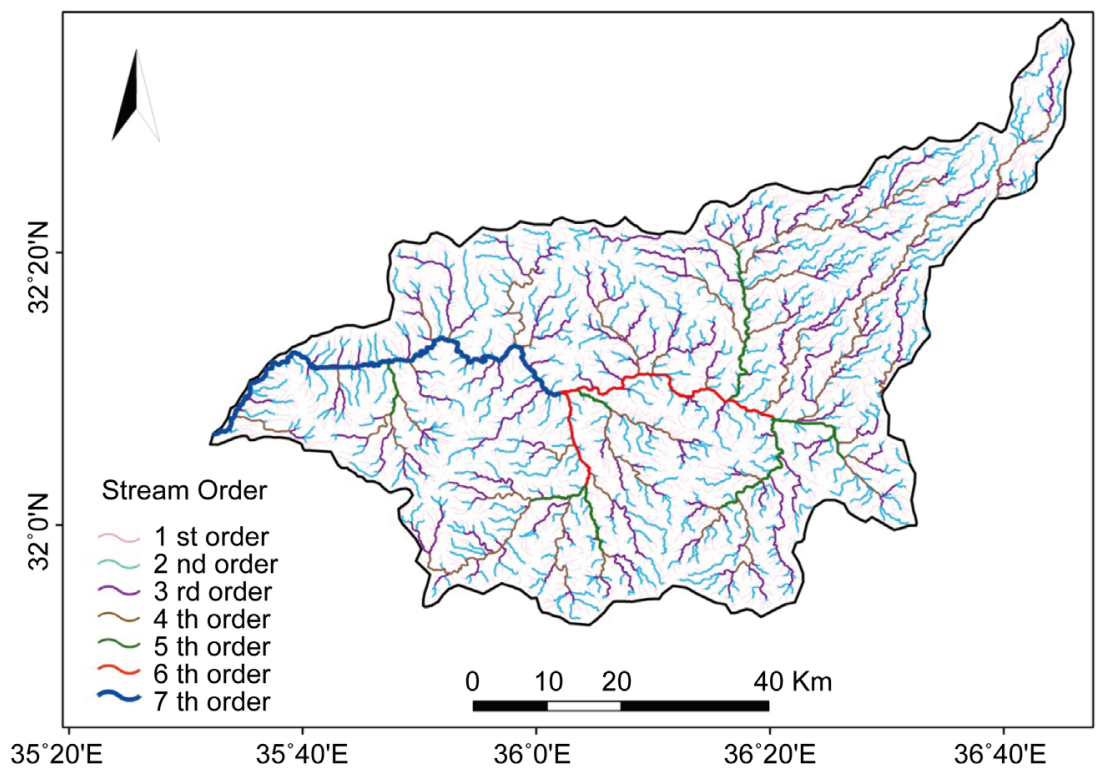

Figure 6. Drainage and stream order of the Zerqa River Watershed. 
Table 3. Morphometric characteristics of the 43 sub-watersheds.

\begin{tabular}{|c|c|c|c|c|c|c|c|c|c|c|c|c|c|c|c|}
\hline \multirow[t]{2}{*}{ Sub-basin } & \multicolumn{5}{|c|}{ Basic Parameters } & \multicolumn{5}{|c|}{ Linear Parameters } & \multicolumn{5}{|c|}{ Shape Parameters } \\
\hline & $A\left(\mathrm{~km}^{2}\right)$ & $P(\mathrm{~km})$ & $\mathbf{u}$ & $\mathrm{L}_{\mathrm{b}}(\mathrm{km})$ & $\mathrm{L}_{\mathrm{u}}(\mathrm{km})$ & $\mathbf{R}_{\mathrm{b}}$ & $D_{d}$ & $\mathrm{~F}_{\mathrm{s}}$ & $\mathrm{T}_{\mathrm{r}}$ & $\mathrm{L}_{\mathrm{o}}$ & $\mathbf{R}_{\mathrm{f}}$ & $\mathrm{B}_{\mathrm{s}}$ & $\mathbf{R}_{\mathrm{e}}$ & $\mathrm{C}_{\mathrm{c}}$ & $\mathbf{R}_{c}$ \\
\hline 1 & 26.25 & 57.5 & 4 & 17 & 9.3 & 4.33 & 0.647 & 1.457 & 0.444 & 0.772 & 0.0908 & 11 & 0.339 & 6.33 & 0.099 \\
\hline 2 & 6.9 & 23.5 & 4 & 7.5 & 7.23 & 1.88 & 2.65 & 2.463 & 1.075 & 0.46 & 0.122 & 8.152 & 0.395 & 5.084 & 0.156 \\
\hline 3 & 7.4 & 24.5 & 4 & 10.6 & 7.52 & 1.44 & 3.162 & 1.756 & 1.8 & 0.349 & 0.0604 & 15.183 & 0.289 & 5.082 & 0.154 \\
\hline 4 & 24.2 & 54.5 & 4 & 19.5 & 8.92 & 2.77 & 1.367 & 1.033 & 1.332 & 0.62 & 0.0636 & 15.712 & 0.284 & 6.25 & 0.102 \\
\hline 5 & 26 & 41.5 & 4 & 22 & 10.2 & 5.11 & 1.525 & 1.769 & 0.862 & 0.59 & 0.0537 & 18.615 & 0.261 & 4.59 & 0.189 \\
\hline 6 & 7 & 28.5 & 4 & 9 & 7.62 & 2.66 & 3.928 & 3.428 & 1.145 & 0.388 & 0.0864 & 11.571 & 0.331 & 6.078 & 0.108 \\
\hline 7 & 10.5 & 36.5 & 4 & 11.5 & 8.32 & 2.44 & 1.725 & 2.095 & 0.823 & 0.456 & 0.0739 & 12.595 & 0.317 & 6.35 & 0.098 \\
\hline 8 & 14.25 & 49.5 & 4 & 14 & 9.15 & 2.88 & 2.995 & 1.824 & 1.641 & 0.508 & 0.0727 & 13.754 & 0.306 & 7.4 & 0.037 \\
\hline 9 & 5.5 & 27.5 & 4 & 6 & 6.46 & 1.77 & 3.781 & 2.909 & 1.299 & 0.458 & 0.152 & 6.545 & 0.44 & 6.61 & 0.091 \\
\hline 10 & 6.6 & 27.9 & 4 & 7.6 & 6.65 & 1.88 & 4.075 & 2.57 & 1.585 & 0.434 & 0.114 & 8.751 & 0.381 & 6.12 & 0.106 \\
\hline 11 & 2.3 & 17.5 & 4 & 5.5 & 5.78 & 1.11 & 5.704 & 4.347 & 1.312 & 0.209 & 0.076 & 13.152 & 0.311 & 6.51 & 0.094 \\
\hline 12 & 4 & 22 & 4 & 8 & 5.91 & 1.33 & 5.575 & 3 & 1.858 & 0.25 & 0.0625 & 16 & 0.282 & 6.2 & 0.103 \\
\hline 13 & 3.4 & 40 & 4 & 9.5 & 6.31 & 1.22 & 4.217 & 3.235 & 1.303 & 0.178 & 0.0376 & 26.544 & 0.218 & 12.24 & 0.026 \\
\hline 14 & 10.15 & 39.5 & 4 & 13 & 7.21 & 2.88 & 2.286 & 2.561 & 0.892 & 0.39 & 0.06 & 16.65 & 0.276 & 6.99 & 0.081 \\
\hline 15 & 12.15 & 34 & 4 & 10.5 & 7 & 1.77 & 1.59 & 1.316 & 1.208 & 0.578 & 0.11 & 9.074 & 0.374 & 5.5 & 0.132 \\
\hline 16 & 3.9 & 17.5 & 4 & 7 & 5.91 & 2.11 & 6.282 & 4.871 & 1.289 & 0.278 & 0.0829 & 12.564 & 0.318 & 5 & 0.159 \\
\hline 17 & 8.3 & 33 & 4 & 10 & 8.11 & 2 & 3.74 & 2.168 & 1.725 & 0.415 & 0.083 & 12.048 & 0.324 & 6.46 & 0.095 \\
\hline 18 & 17.2 & 36.5 & 4 & 11.8 & 8.42 & 1 & 1.587 & 0.523 & 3.017 & 0.728 & 0.123 & 8.095 & 0.396 & 4.96 & 0.162 \\
\hline 19 & 19.5 & 57 & 4 & 15.5 & 8.9 & 4.22 & 1.899 & 1.948 & 0.974 & 0.629 & 0.0811 & 12.32 & 0.321 & 7.28 & 0.075 \\
\hline 20 & 22.1 & 41 & 4 & 14.5 & 8.51 & 2.55 & 2.118 & 1.04 & 2.036 & 0.762 & 0.105 & 9.315 & 0.365 & 4.92 & 0.165 \\
\hline 21 & 58.2 & 87 & 4 & 16.5 & 11.3 & 9.77 & 1.106 & 1.512 & 0.731 & 1.763 & 0.213 & 4.677 & 0.521 & 6.43 & 0.096 \\
\hline 22 & 34.65 & 22.4 & 4 & 31.5 & 15.5 & 4.66 & 0.401 & 1.212 & 0.33 & 0.55 & 0.0349 & 28.636 & 0.21 & 2.14 & 0.867 \\
\hline 23 & 53.65 & 59.5 & 4 & 17.5 & 6 & 5.55 & 0.356 & 0.931 & 0.382 & 1.532 & 0.175 & 5.708 & 0.472 & 4.58 & 0.19 \\
\hline 24 & 34.45 & 77 & 4 & 26.5 & 4 & 5 & 0.511 & 1.306 & 0.391 & 0.65 & 0.049 & 20.384 & 0.249 & 7.4 & 0.072 \\
\hline 25 & 8.4 & 37.5 & 4 & 14 & 1.5 & 2.33 & 0.922 & 2.5 & 0.368 & 0.3 & 0.0428 & 23.333 & 0.233 & 7.3 & 0.075 \\
\hline 26 & 23.2 & 79.5 & 4 & 31 & 14 & 3 & 0.775 & 1.163 & 0.666 & 0.374 & 0.0241 & 41.422 & 0.175 & 9.31 & 0.046 \\
\hline 27 & 9.5 & 40.5 & 4 & 18.5 & 3.5 & 1.44 & 0.826 & 1.052 & 0.785 & 0.256 & 0.027 & 36.026 & 0.187 & 7.41 & 0.072 \\
\hline 28 & 19.8 & 63 & 4 & 20.5 & 5 & 1.11 & 0.452 & 1.11 & 0.406 & 0.482 & 0.047 & 21.224 & 0.244 & 7.98 & 0.062 \\
\hline 29 & 15.5 & 37 & 4 & 16.5 & 5.5 & 1.33 & 0.363 & 1.354 & 0.268 & 0.469 & 0.056 & 17.564 & 0.269 & 5.3 & 0.153 \\
\hline 30 & 33.6 & 64.5 & 4 & 24 & 5.7 & 4.88 & 0.732 & 1.726 & 0.424 & 0.7 & 0.058 & 17.142 & 0.272 & 6.27 & 0.101 \\
\hline 31 & 22.75 & 82.5 & 4 & 27 & 10.15 & 4.55 & 3.467 & 1.802 & 1.923 & 0.421 & 0.0312 & 32.043 & 0.199 & 9.76 & 0.041 \\
\hline 32 & 11.5 & 62.5 & 4 & 22.5 & 9.88 & 1.77 & 3.578 & 1.391 & 2.572 & 0.255 & 0.0227 & 44.021 & 0.17 & 10.4 & 0.036 \\
\hline 33 & 3.75 & 35.5 & 4 & 11.4 & 7.34 & 2.55 & 6.082 & 6.133 & 0.991 & 0.164 & 0.0288 & 34.656 & 0.191 & 10.43 & 0.037 \\
\hline 34 & 8.2 & 38.5 & 4 & 12.4 & 7.5 & 2.44 & 3.624 & 2.682 & 1.351 & 0.33 & 0.0533 & 18.751 & 0.26 & 7.58 & 0.069 \\
\hline 35 & 27 & 78.5 & 4 & 25.5 & 9.12 & 5.44 & 6.081 & 1.814 & 3.352 & 0.529 & 0.0415 & 24.083 & 0.229 & 8.52 & 0.055 \\
\hline 36 & 8 & 28.5 & 4 & 10.14 & 6.69 & 1.44 & 2.683 & 1.625 & 1.651 & 0.394 & 0.0788 & 12.852 & 0.314 & 5.68 & 0.123 \\
\hline 37 & 21 & 52 & 4 & 16 & 9.7 & 4.44 & 2.118 & 1.904 & 1.112 & 0.656 & 0.082 & 12.19 & 0.323 & 6.4 & 0.097 \\
\hline 38 & 23.2 & 46 & 4 & 4.4 & 9.42 & 4.88 & 2.205 & 1.896 & 1.162 & 2.761 & 1.198 & 0.834 & 1.234 & 5.38 & 0.137 \\
\hline 39 & 5.15 & 32 & 4 & 8.5 & 6.9 & 2 & 2.35 & 3.495 & 0.672 & 0.302 & 0.0712 & 14.029 & 0.301 & 7.95 & 0.063 \\
\hline 40 & 18.25 & 47.5 & 4 & 13.5 & 9.2 & 4.55 & 3.104 & 2.246 & 1.382 & 0.675 & 0.1 & 9.986 & 0.356 & 6.27 & 0.101 \\
\hline 41 & 38.8 & 79 & 4 & 18 & 10 & 4.22 & 1.586 & 0.979 & 1.62 & 1.077 & 0.119 & 8.35 & 0.39 & 7.15 & 0.078 \\
\hline 42 & 14.9 & 31 & 4 & 12.5 & 9.94 & 3 & 2.631 & 1.812 & 1.451 & 0.596 & 0.095 & 10.486 & 0.348 & 4.53 & 0.194 \\
\hline 43 & 35.5 & 51 & 4 & 20 & 9.49 & 3.77 & 1.275 & 1.014 & 1.257 & 0.887 & 0.088 & 11.267 & 0.336 & 4.83 & 0.171 \\
\hline
\end{tabular}


and relief of the catchment, the influence of compressional structures, the stage of geomorphic development, and rejuvenation processes affecting the watershed. The values of bifurcation ratio for the Zerqa River catchment and the 43 subwatersheds are indicative of structural distortion affecting the drainage system $\left(\mathrm{R}_{\mathrm{b}}\right.$ varied from 2.7 to 5 , with an average of 4.9). Relative relief and slope steepness are the main morphological factors controlling drainage density $\left(D_{d}\right)$. Low drainage density occurred where the catchment relief is high [56]. Nevertheless, other factors determining $D_{d}$ are: the resistance of surface materials against erosion, and the infiltration-capacity of the soil. The $D_{d}$ value of the entire catchment is 1.46 , which denotes a moderate to well-drained catchment. The presence of dissected and steep slopes with relatively impervious underlying rocks, i.e., the marly-clay unit, and the limestone-marly unit, exposed at the middle reaches, resulted in a series of springs out flowing to the major courses of the Zerqa River. The watershed exhibits a fine drainage texture $\left(D_{t}\right)$, which approaches 15.4. High $D_{t}$ values indicate the presence of fragile slope materials and soft rocks where high sediment yield has been recorded [13]. The $\mathrm{F}_{\mathrm{s}}$ value for the Zerqa River catchment is 1.186, and for the 43 sub-watersheds ranges from 0.979 to 6.133 . Low $F_{s}$ values denote that a relatively low infiltration rate of surface water is assumed; consequently, the groundwater potential is relatively low. Values of elongation ratio $\left(R_{e}\right)$ vary between 0.6 to 1.0 over a wide range of geological and climatic conditions [56]. The elongation ratio $\left(\mathrm{R}_{\mathrm{e}}\right)$ for the Zerqa River watershed is 0.248 , and the values for the 43 sub-watersheds range from 0.17 to 0.234 . Such values are indicative of elongated shape, and are combined with steep valley-side slopes and high relief. The $R_{c}$ value for the Zerqa River catchment is 0.284 , whereas [57] argued that watersheds with a range of circularity ratios $\left(R_{c}\right)$ of 0.4 to 0.5 are considered as strongly elongated and at the youth stage of geomorphic evolution. The form factor $\left(R_{f}\right)$ value for the Zerqa River is 0.236 . Low $R_{f}$ values indicate that low peak flows of long duration are expected for the catchment [73]. High basin relief $\left(B_{h}\right)$ of the Zerqa River watershed $(1949 \mathrm{~m})$ denotes high potential erosion energy of the drainage system. Due to continuous changes of base level of the Dead Sea and Jordan River, and tectonic activity, the Zerqa River entailed progressive down-cutting and incision through its geomorphic history, giving, rise to the present dissected and rough terrain. High rates of annual soil erosion loss and sediment yield, and landslide activity are predominant in present-day geomorphic processes. The hypsometric integral (HI) for the Zerqa River catchment is found to be 0.834 [74], which is indicative of recurrent phases of rejuvenation and youth-age stage of geomorphic development. The basic morphometric parameters calculated for the 43 sub-watersheds (Table 3 ) are: area $(A)$, perimeter $(P)$, stream order $(\mathrm{u})$, basin length $\left(\mathrm{L}_{\mathrm{b}}\right)$ and total stream length $\left(\mathrm{L}_{\mathrm{u}}\right)$.

\subsubsection{Basic Morphometric Parameters}

1) Sub-Watershed Area (A) and Perimeter (P)

The most significant hydrological characteristics of a watershed is the drai- 
nage area. It reflects the volume of water that can be generated from precipitation. The present investigation reveals that sub-watershed no. 13 has a minimum area of $3.4 \mathrm{~km}^{2}$. The watershed perimeter represents the length of a line that delineates the water divide of the sub-watersheds. P parameter can be employed as an indicator of watershed size and shape. The maximum and minimum values are $82.5 \mathrm{~km}^{2}$ for sub-watershed no. 31 and $17.5 \mathrm{~km}^{2}$ for sub-watersheds no. 11 , and no. 16.

\section{2) Stream Order $(u)$}

Although Gravelius [75], Horton [54], Strahler [55] [56] and Scheidegger [76] have elaborated different methods of ordering streams, Strahler's method of stream ordering is employed due to its simplicity, and because it is the most commonly used system in hydrological studies [77] [78].

\section{3) Basin Length $\left(L_{b}\right)$}

The basin length $\left(\mathrm{L}_{\mathrm{b}}\right)$ parameter is defined as the ratio of the largest dimension of a watershed, to its main channel. $\mathrm{L}_{b}$ parameter is measured along the main channel from the watershed outlet to the basin divide. Patel et al. [36] argued that the $\mathrm{L}_{\mathrm{b}}$ parameter is fundamental in hydrological computation and increases as the drainage increases and vice versa. Basin length $\left(L_{b}\right)$ is considered a watershed input parameter to compute the major shape parameters. The basin length for the 43 sub-watersheds ranges from $6 \mathrm{~km}$ to $31.5 \mathrm{~km}$.

\section{4) Total Length of Streams $\left(L_{u}\right)$}

The number of streams pertaining to different orders for each sub-watershed was computed, and their lengths are measured (Table 3). The first-order stream has no tributary and its flow depends totally on the surface overland flow related to it. Further, the second-order stream is formed by the junction of two firstorder streams and as such has a higher flow, and the third-order streams receive flow from the two second-order streams [37]. All sub-watersheds in the present study are of fourth-order, but the total stream length of all orders varies remarkably. Among the 43 sub-watersheds, sub-watershed no. 22 ha the greatest total length of streams $(15.5 \mathrm{~km})$, while, sub-watershed no. 25 has the lowest total length of streams $(1.5 \mathrm{~km})$. It is notable, that the greatest total length of streams is restricted to sub-watersheds deformed by major compressional structures dominating the western part of the Zerqa River Watershed.

\subsubsection{Linear Parameters}

The linear parameters which are considered in the prioritization process of subwatersheds are: bifurcation ratio $\left(R_{b}\right)$, drainage density $\left(D_{d}\right)$, stream frequency $\left(\mathrm{F}_{\mathrm{s}}\right)$, texture ration $\left(\mathrm{T}_{\mathrm{r}}\right)$, and length of overland flow $\left(\mathrm{L}_{\mathrm{o}}\right)$.

\section{1) Bifurcation Ratio $\left(R_{b}\right)$}

Horton [54] defined the bifurcation ratio $\left(R_{b}\right)$ as the ratio of the streams number of a given order to the number of the streams of the next higher order. It is predetermine as an index of relief and dissection. $R_{b}$ values of drainage basins often range between 2 for flat/rolling topography and 6 for watersheds controlled by geological structure where the drainage network is highly distorted. 
Conversely, low values of bifurcation ratio dominate catchments without any distortion of drainage systems [55] [56]. However, it is stated that negligible variation in $\mathrm{R}_{\mathrm{b}}$ values exists among regions of different geologic and geomorphic setting, except where geological and structural control predominate. Hydrological characteristics of watersheds can be correlated with $R_{b}$ values. High $R_{b}$ values denote high overland flow and early hydrograph peak with a high potential of susceptibility to flash flooding during intense rainfall storms [79]. This in turn increases soil erosion rates and sediment discharge into the main channels. Notable variation is observed in $R_{b}$ values at the Zerqa River watershed (Table 3). Sub-watershed no. 18 , for example, has a minimum $R_{b}$ of 1 , whereas, subwatersheds nos. 21, 5, 23 and 35 have maximum $\mathrm{R}_{\mathrm{b}}$ ratios of 9.77, 5.11 and 5.44 respectively. The $R_{b m}$ value for the entire Zerqa River watershed is 4.897. It is clear that $\mathrm{R}_{\mathrm{b}}$ values are relatively high, for sub-watersheds occupying the western part of the catchment.

\section{2) Drainage Density $\left(D_{d}\right)$}

Drainage density emphasizes the closeness of spacing of channels. It is computed as the total length of streams in a catchment per unit area, therefore, it is a measure of terrain dissection and runoff potential of the watershed. A high value of $D_{d}$ indicates a relatively high density of streams, high runoff, a quick stream response, and consequently, a low infiltration rate. By contrast, low drainage density of a watershed implies low runoff and high infiltration [80]. Relative relief and slope steepness are major factors controlling drainage density. Thus, low drainage density occurs where basin relief $\left(B_{h}\right)$ is high as in the case of the Zerqa River catchment $\left(B_{h}\right.$ is $\left.1949 \mathrm{~m}\right)$. Other fundamental factors controlling $D_{d}$ are infiltration-capacity of the soil, and initial resistance of land against erosion. Poorly drained catchments often have a $\mathrm{D}_{\mathrm{d}}$ value of 2.74 , while a well-drained one has a lower value of 0.73 , or one fourth as large [54]. Regardless of the degraded vegetation cover, low $D_{d}$ values denote the presence of highly dissected steep topography, and impervious underlying bed rock. The $D_{d}$ value for the Zerqa River catchment is 1.477 , while $\mathrm{D}_{\mathrm{d}}$ values for the 43 sub-watersheds range from 0.356 (sub-watershed no. 23) to 6.282 (sub-watershed no. 16) (Table 3). According to Deju [81] classification of $D_{d}, 6$ sub-watersheds are categorized as watersheds with poordrainage density (0.5), and 11 as sub-watersheds of medium drainage density $(0.5-1.5)$. Whereas, 26 sub-watersheds are of excellent drainage density (>1.5).

\section{3) Stream Frequency $\left(F_{s}\right)$}

Stream frequency $\left(\mathrm{F}_{\mathrm{s}}\right)$ indicates the ratio of the total number of streams $\left(\mathrm{N}_{\mathrm{u}}\right)$ in a watershed to the watershed area (A). It is identified as the number of streams per unit area [54]. Generally, values of $F_{s}$ vary from 3.91 to 9.99 , depending mainly on the underlying bedrock of the drainage basin. Thus, reflecting the texture of the drainage network. $\mathrm{F}_{\mathrm{s}}$ values are positively correlated with $D_{d}$ values of the catchment. This means that any increase in stream population is connected to that of drainage density [73]. For small and large drainage basins, the values of $F$ s and $D_{d}$ are not directly comparable because they usually vary 
with the size of the drainage area. High stream frequency indicates more percolation in slope materials and bedrock, and thus more groundwater potential is expected. The values of stream frequency $\left(F_{s}\right)$ for the 43 sub-watershed range from 0.979 (sub-watershed no. 41) to 6.133 (sub-watershed 33) (Table 3), and the $\mathrm{F}_{\mathrm{s}}$ for the Zerqa River catchment is 1.86 [74].

\section{4) Texture Ratio $\left(T_{r}\right)$}

$T_{r}$ is calculated as the ratio of the total number of streams of the first order $\left(N_{1}\right)$ to the perimeter of the watershed. $\mathrm{T}_{\mathrm{r}}$ parameter is considered to be one of the most significant factors in drainage basin morphometry. Texture ratio depends on the underlying lithology and surface materials, infiltration capacity, and the relief aspect of the terrain [82]. The value of Texture ratio for the Zerqa River watershed is 1.463 , and for the sub-watersheds ranges from 0.268 (sub-watershed no. 29) to 3.352 (sub-watershed no. 35). Such values indicate that the watershed is of relatively high runoff.

\section{5) Length of Overland Flow $\left(\mathrm{L}_{0}\right)$}

$\mathrm{L}_{\mathrm{o}}$ refers to the length of water over the ground before it becomes concentrated into definite stream channels, and is equal to half of the drainage density [54]. The length of overland flow relates inversely to the important independent parameters affecting both hydrologic and hydrographic development of drainage basins [54] [82]. The length of overland flow for the Zerqa River watershed is $0.730 \mathrm{~km}$, and for the sub-watersheds ranges from $0.164 \mathrm{~km}$ (sub-watershed no. 33 ) and $2.761 \mathrm{~km}$ (sub-watershed no. 38).

\subsubsection{Shape Parameters}

Shape parameters include shape factor $\left(B_{s}\right)$, form factor $\left(R_{f}\right)$, elongation ratio $\left(\mathrm{R}_{\mathrm{e}}\right)$, compactness coefficient (ratio) $\left(\mathrm{C}_{\mathrm{c}}\right)$, and circularity ratio $\left(\mathrm{R}_{\mathrm{c}}\right)$.

\section{1) Shape Factor $\left(B_{s}\right)$}

Shape factor refers to the ratio of the square of the basin length to the area of the basing $\left(\mathrm{L}_{\mathrm{b}}^{2} / \mathrm{A}\right)$. This parameter is in increase proportion to the form factor [46] [54]. Shape factor provides a conception regarding the circular character of the watershed. The greater the circular character of the catchment, the greater is the fast response of the catchment following an intense heavy rainstorm [83]. The shape factor for the entire Zerqa River watershed is 4.52 , whereas, the 43 sub-watersheds exhibit a range of 0.834 to 9.986 , which indicates that elongated shapes dominate the sub-watersheds.

\section{2) Form Factor $\left(R_{f}\right)$}

$\mathrm{R}_{\mathrm{f}}$ indicates the ratio of the area of the watershed to the square of the basin length [55] [56]. Thus, higher values of form factor indicate a more circular shape of the watershed, and, the smaller the value of $R_{f}(<0.45)$, the more the watershed will be elongated. The catchments with high $\mathrm{R}_{\mathrm{f}}$ values are characterized by high peak flow of shorter duration, while elongated sub-watersheds with low form factor, indicate a low peak flow of longer duration. The $\mathrm{R}_{\mathrm{f}}$ value for the Zerqa River watershed is 0.236 , and for the 43 sub-watersheds less than 0.3 , which indicates the dominance of elongated shape associated with low peak 
flows for longer duration and as such less probability for severe flooding (Table 3).

\section{3) Elongation Ratio $\left(R_{e}\right)$}

$R_{e}$ refers to the ratio between the diameter of the circle of the same area as presented by the drainage basin to the maximum basin length [58]. It has been stated that $R_{e}$ values generally vary between 0.6 and 1.0 over a wide range of geological and climatic conditions [56]. $\mathrm{R}_{\mathrm{e}}$ values close to 1.0 are characteristic of regions with low relief, whereas values in the range of $0.6-0.8$ represent watersheds with high relief and steep slopes. The low values of $R_{e}$ indicate that a particular sub-watershed is more elongated than others. Where the $R_{e}$ value approaches 1.0, the shape of the watershed becomes a circle shape [58]. The elongated shape of a watershed indicates a younger stage of evolution, caused by intense neotectonic activity, while the intermediate shape with a tendency to circularity suggests an early mature stage [84], and is more efficient in discharge runoff than elongated watersheds. Based on $\mathrm{R}_{\mathrm{e}}$ values, watersheds were categorized into five groups, i.e. circular $(0.9$ - 1.0), oval (0.8 - 0.9), less elongated (0.7 $0.8)$, elongated $(0.5-0.7)$, and more elongated $(<0.5)$. The elongated ration of the Zerqa River catchment is 0.530 , whereas values of $R_{e}$ for the 43 sub- watersheds range from 0.170 to 0.521 , thus, most of the sub-watersheds are more elongated, and a few of them are elongated.

\section{4) Compactness Coefficient $\left(C_{c}\right)$}

Compactness coefficient $\left(C_{c}\right)$ is elaborated by Gravelius [75], thus is also known as the Gravelius index $\left(\mathrm{G}_{\mathrm{I}}\right)$. It defined as the ratio of perimeter of watershed to circumference of circle area, which is equal to the area of the watershed. When $\mathrm{C}_{\mathrm{c}}$ value is 1 , it means that the catchment is a perfect circle. If the $\mathrm{C}_{\mathrm{c}}$ value is 1.28 , the basin is more square-shaped, while the basin is considered a very elongated one, when the $C_{c}$ value $>3.0$ [85]. The $C_{c}$ parameter is independent of size of the watershed and dependent only on slope [54]. A circular basin yields the shorter time of concentration before the peak flow realized in the watershed, and $\mathrm{C}_{\mathrm{c}}>1.0$ indicates more deviation from the circular nature [82]. Lower values of $\mathrm{Cc}$ imply more elongation and high erosion. The $\mathrm{C}_{\mathrm{c}}$ value for the Zerqa River watershed is 1.87 , whereas the $C_{c}$ values for most of the 43 subwatersheds are greater than 3 , which reflects high erosion.

\section{5) Circularity Ratio $\left(R_{c}\right)$}

$R_{c}$ is the ratio of basin area (A) to the area of circle having the same circumference as the perimeter $(\mathrm{P})$ of the watershed [57]. Circularity is the most useful shape morphometric measure in correlation with stream discharge. The general trend is that $R_{c}$ value decreases with increasing stream order. Zavoianu [85] argued that the ratio is equal to unity when the watershed shape is a perfect circle, decreasing to 0.785 when the basin is a square, and continues to decrease to the extent to which the catchment becomes elongated. According to Miller [57], $\mathrm{R}_{\mathrm{c}}$ is influenced by the length and frequency of streams, geological structures, relief and slope steepness, climate, and land use/land cover of the watershed. Drainage basins with a range of circularity ratios of 0.4 to 0.5 are strongly elongated [57], 
with low discharge of runoff and the subsoil of high permeability. The circularity ratio for the Zerqa River watershed is 0.284 , whereas, the $R_{c}$ values for 42 sub-watersheds are less than 0.2 , and for one sub-watershed (no. 22), the $R_{c}$ value is 0.867 .

\subsection{Prioritization of Sub-Watersheds Based on Morphometric Analysis}

Morphometric analysis was recently employed extensively for prioritization of watersheds of different size (sub-watersheds, mini-watersheds, and microwatersheds) for soil and water conservation [35] [36] [37] [42] [43] [44] [45] [46] [56] [57] [58] [59] [86] [87]. Erosion risk parameters related to linear and shape morphometric parameters were used for prioritizing sub-watersheds are: the bifurcation ratio $\left(R_{b}\right)$, stream frequency $\left(F_{s}\right)$, drainage density $\left(D_{d}\right)$, length of overland flow $\left(\mathrm{L}_{\mathrm{o}}\right)$, and texture ratio $\left(\mathrm{T}_{\mathrm{r}}\right)$. Additionally, the shape morphometric variables include: form factor $\left(\mathrm{R}_{\mathrm{f}}\right)$, compactness coefficient $\left(\mathrm{C}_{\mathrm{c}}\right)$, shape factor $\left(\mathrm{B}_{\mathrm{s}}\right)$, elongation ratio $\left(R_{e}\right)$, and circularity ratio $\left(R_{c}\right)$. Based on the range of calculated compound parameter $\left(C_{p}\right)$ values (Table 4 ), the 43 sub-watersheds of the Zerqa River were classified into three priority groups:

(i) High priority (14.0 - 20.9)

(ii) Moderate priority (21.0 - 24.9)

(iii) Low priority (25.0 - 27.9)

Using Arc GIS, the spatial distribution of the 43 sub-watershed groups based on the compound parameter $\left(\mathrm{C}_{\mathrm{p}}\right)$ values was established. Figure 7 shows priority groups of sub-watershed $\mathrm{S}$ for soil and water conservation. Accordingly, the highest priority indicates the greater degree of erosion risk associated with a particular sub-watershed, and it becomes a potential area for adaptation of soil con-

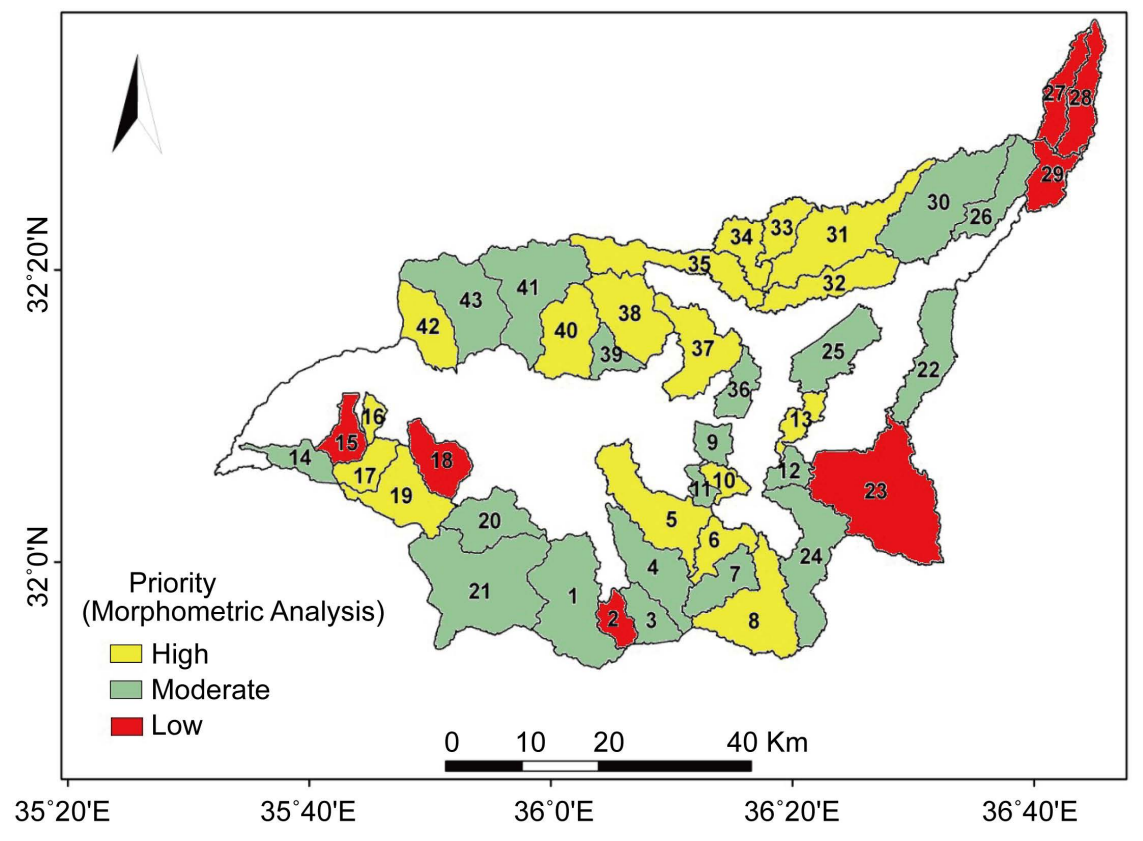

Figure 7. Priority of the 43 sub-watersheds based on based on morphometric analysis. 
Table 4. Calculation of compound parameters and prioritized ranks based on morphometric analysis.

\begin{tabular}{|c|c|c|c|c|c|c|c|c|c|c|c|c|c|}
\hline Sub-basin & $\mathbf{R}_{\mathrm{b}}$ & $\mathrm{D}_{\mathrm{d}}$ & $F_{s}$ & $\mathrm{~T}_{\mathrm{r}}$ & $\mathrm{L}_{\mathrm{o}}$ & $\mathbf{R}_{\mathbf{f}}$ & $\mathrm{B}_{s}$ & $\mathbf{R}_{\mathrm{e}}$ & $\mathrm{C}_{c}$ & $\mathbf{R}_{\mathrm{c}}$ & $\begin{array}{l}\text { Compound } \\
\text { Parameters }\end{array}$ & $\begin{array}{l}\text { Prioritized } \\
\text { ranks }\end{array}$ & Priority \\
\hline 1 & 12 & 38 & 29 & 36 & 6 & 31 & 12 & 31 & 21 & 23 & 23.9 & 26 & Moderate \\
\hline 2 & 30 & 18 & 13 & 26 & 23 & 38 & 43 & 38 & 10 & 35 & 27.4 & 33 & Low \\
\hline 3 & 35 & 14 & 25 & 7 & 33 & 17 & 24 & 19 & 9 & 34 & 21.7 & 18 & Moderate \\
\hline 4 & 20 & 31 & 39 & 16 & 14 & 19 & 25 & 18 & 18 & 26 & 22.6 & 21 & Moderate \\
\hline 5 & 4 & 30 & 24 & 30 & 16 & 13 & 30 & 13 & 4 & 40 & 20.4 & 10 & High \\
\hline 6 & 21 & 8 & 5 & 24 & 31 & 29 & 14 & 29 & 15 & 29 & 20.5 & 11 & High \\
\hline 7 & 24 & 26 & 16 & 31 & 25 & 22 & 19 & 24 & 22 & 22 & 23.1 & 24 & Moderate \\
\hline 8 & 18 & 16 & 20 & 10 & 20 & 21 & 22 & 21 & 32 & 3 & 18.3 & 3 & High \\
\hline 9 & 32 & 9 & 8 & 19 & 24 & 40 & 4 & 40 & 27 & 17 & 22.0 & 19 & Moderate \\
\hline 10 & 31 & 7 & 10 & 12 & 26 & 36 & 7 & 36 & 16 & 28 & 20.9 & 14 & High \\
\hline 11 & 41 & 4 & 3 & 17 & 41 & 23 & 21 & 22 & 26 & 18 & 21.6 & 71 & Moderate \\
\hline 12 & 38 & 5 & 7 & 6 & 40 & 18 & 26 & 17 & 17 & 27 & 20.1 & 7 & Moderate \\
\hline 13 & 40 & 6 & 6 & 18 & 42 & 7 & 36 & 7 & 43 & 1 & 20.6 & 12 & High \\
\hline 14 & 19 & 21 & 11 & 29 & 30 & 16 & 27 & 16 & 28 & 16 & 21.3 & 15 & Moderate \\
\hline 15 & 33 & 27 & 32 & 22 & 17 & 35 & 8 & 35 & 13 & 31 & 25.3 & 30 & Low \\
\hline 16 & 27 & 1 & 2 & 20 & 37 & 27 & 18 & 25 & 8 & 36 & 20.1 & 7 & High \\
\hline 17 & 28 & 10 & 15 & 8 & 28 & 28 & 15 & 28 & 25 & 19 & 20.4 & 10 & High \\
\hline 18 & 43 & 28 & 43 & 2 & 8 & 39 & 5 & 39 & 7 & 37 & 25.1 & 92 & Low \\
\hline 19 & 13 & 25 & 17 & 28 & 13 & 25 & 17 & 26 & 30 & 13 & 20.7 & 31 & High \\
\hline 20 & 22 & 23 & 38 & 4 & 7 & 34 & 9 & 34 & 6 & 38 & 21.5 & 61 & Moderate \\
\hline 21 & 1 & 33 & 28 & 33 & 2 & 42 & 2 & 42 & 24 & 20 & 22.7 & 22 & Moderate \\
\hline 22 & 8 & 41 & 34 & 42 & 18 & 6 & 37 & 6 & 1 & 43 & 23.6 & 25 & Moderate \\
\hline 23 & 2 & 43 & 42 & 40 & 3 & 41 & 3 & 41 & 3 & 41 & 25.6 & 13 & Low \\
\hline 24 & 5 & 39 & 33 & 39 & 12 & 11 & 32 & 11 & 33 & 11 & 24.6 & 21 & Moderate \\
\hline 25 & 26 & 34 & 12 & 41 & 36 & 9 & 34 & 9 & 31 & 14 & 24.4 & 28 & Moderate \\
\hline 26 & 16 & 36 & 35 & 35 & 32 & 2 & 41 & 2 & 39 & 6 & 27.0 & 27 & Moderate \\
\hline 27 & 36 & 35 & 37 & 32 & 38 & 3 & 40 & 3 & 34 & 12 & 24.4 & 32 & Low \\
\hline 28 & 42 & 40 & 36 & 38 & 21 & 10 & 33 & 10 & 37 & 8 & 27.5 & 34 & Low \\
\hline 29 & 39 & 42 & 31 & 43 & 22 & 14 & 29 & 14 & 11 & 33 & 27.8 & 35 & Low \\
\hline 30 & 6 & 37 & 26 & 37 & 9 & 15 & 28 & 15 & 19 & 24 & 21.6 & 17 & Moderate \\
\hline 31 & 9 & 13 & 23 & 5 & 27 & 5 & 38 & 5 & 40 & 5 & 17.0 & 2 & High \\
\hline 32 & 34 & 12 & 30 & 3 & 39 & 1 & 42 & 1 & 41 & 2 & 20.5 & 11 & High \\
\hline 33 & 23 & 2 & 1 & 27 & 43 & 4 & 39 & 4 & 42 & 4 & 18.9 & 5 & High \\
\hline 34 & 25 & 11 & 9 & 15 & 34 & 12 & 31 & 12 & 35 & 10 & 19.4 & 6 & High \\
\hline 35 & 3 & 3 & 21 & 1 & 19 & 8 & 35 & 8 & 38 & 7 & 14.3 & 1 & High \\
\hline 36 & 37 & 17 & 27 & 9 & 29 & 24 & 20 & 23 & 14 & 30 & 23.0 & 32 & Moderate \\
\hline 37 & 11 & 24 & 18 & 25 & 11 & 26 & 16 & 27 & 23 & 21 & 20.2 & 8 & High \\
\hline 38 & 7 & 22 & 19 & 23 & 1 & 43 & 1 & 43 & 12 & 32 & 20.3 & 9 & High \\
\hline 39 & 29 & 20 & 4 & 34 & 35 & 20 & 23 & 20 & 36 & 9 & 23.0 & 23 & Moderate \\
\hline 40 & 10 & 15 & 14 & 14 & 10 & 33 & 10 & 33 & 20 & 25 & 18.4 & 4 & High \\
\hline 41 & 14 & 29 & 41 & 11 & 4 & 37 & 6 & 37 & 29 & 15 & 22.3 & 20 & Moderate \\
\hline 42 & 17 & 19 & 22 & 13 & 15 & 32 & 11 & 32 & 2 & 42 & 20.5 & 11 & High \\
\hline 43 & 15 & 32 & 40 & 21 & 5 & 30 & 13 & 30 & 5 & 39 & 23.0 & 23 & Moderate \\
\hline
\end{tabular}


servation measures [43]. Out of the 43 sub-watersheds of the Zerqa River, 17 sub-watersheds (39.5\% of the total) (sub-watersheds nos. 5, 6, 7, 10, 13, 16, 17, $19,31,32,33,34,35,37,38,40$, and 42) came under high priority (Figure 7). These sub-watersheds have the highest value of slope, and are heavily influenced by progressive rejuvenation, and deep and shallow landslides, where dissected terrain and steep slopes are characteristic. Furthermore, all these sub-watersheds are affected by the major compressional structure exposed in the western part of the Zerqa River watershed. The spatial distribution of sub-watersheds characterized with high erosion potential, and categorized under high priority for soil conservation, is controlled noticeably by tectonic and structure, geomorphic, lithological and climatic factors. Due to high erosivity character, these subwatersheds need urgent attention for executing soil conservation practices. Nineteen sub-watersheds ( $44.2 \%$ of the total) are classified as moderate priority for soil conservation (sub-watersheds nos: 1, 3, 4, 7, 9, 11, 12, 14, 20, 21, 22, 24, 5, 26, $30,36,39,41$, and 43). These sub-watersheds are located in the basalt geomorphic unit. Arid climate conditions prevail, with low annual rainfall, and minimal vegetation cover. Thus, bare lands are persistent. Most of the land accommodated in these sub-watersheds is utilized as poor rangeland. The third category of sub-watersheds is assigned low priority. It consists of seven sub-watersheds ( $16.3 \%$ of the total) as follows: $2,15,18,23,28,29$. Three of these sub-watersheds $(2,15$, and 18$)$ are located in the rejuvenation belt close to the first category of priority, whereas the other four sub-watersheds are included in the basalt terrain. Rainfed agriculture is practiced over most of the sub-watersheds ranked as high prioritization for soil conservation. The expansion of cultivated cereals to the east towards marginal areas, increases the susceptibility of soil erosion. Moreover, northern and southern highland watersheds are exposed to excessive rates of soil erosion loss due to high soil erodibility, steep slopes, poor conservation control, low vegetation cover (Figure 7, Table 4) and misuse of land resources [14] [15]. Soil erosion becomes more serious on moderate and steep slopes transformed into cultivated land. The transformation of enormous areas of wood and rangeland into farming practices, and the expansion of rainfed "mixed farming" (especially cereals farming) accelerates soil erosion. Thus, cultivated lands with poor conservation measures exhibit a higher rate of soil erosion and decline in soil fertility. Subsequently, all sub-watersheds ranked under high priority, are highly vulnerable to soil erosion, and landslide activity; consequently, they should be prioritized for conservation. Photo-interpretation and field observation carried out earlier in the highland and rainfed areas, indicated that most of mixed rainfed farming lands exhibited typical up and down slope tillage without conservation measures (i.e., contouring and terracing). The highest soil loss values recorded are spatially correlated with rainfed and irrigated farming, barren land, rangeland, and steep slopes $\left(0^{\circ}-6^{\circ}, 6^{\circ}-15^{\circ}, 15^{\circ}-25^{\circ}\right.$ slope categories), poor protective land cover, soft rock and week structures, and the presence of old degraded landslides. There is an abundance of shallow landslides and soil slumping, and a remarkable increase of built-up areas and 
impervious road networks [14] [15]. Never the less, the estimated average annual soil loss rate in the several highland watersheds and rainfed agricultural areas was found to exceed the acceptable soil loss tolerance limits ( 2 - 12 ton $\cdot \mathrm{ha}^{-1} \cdot \mathrm{year}^{-1}$ ) for the Mediterranean environments [88] [89] [90]. Therefore, priority must be given to the protection of sub-watersheds exposed to high soil erosion rates, and with degraded vegetation cover.

\subsection{Prioritization of Sub-Watersheds Based on Principal Component Analysis (PCA)}

Principal Component analysis (PCA) was conducted on 13morphometric parameters as an efficient technique to express the physical behavior, and relationships between morphometric variables for a semi arid watershed with relatively poor hydrological records. Instead of using a correlation matrix, which affirms numerically the degree of association between every pairs of variables, PCA utilizes a "component loading" matrix, which expresses numerically the level of relationship between them and the original morphometric parameters. The weights of the original parameters in each component are called "loadings", and each component is associated with a particular parameter. Besides interpreting the processes that generate the observed relationships between the chosen variables, PCA also provides a simplified data matrix known as the "component score" (or weightings) matrix [91]. The original 13 morphometric parameters were reduced to two significant components as illustrated by the "component loading matrix", and the relationships between the rotated components and the original parameters are occasionally accommodated in the component loading matrix. These relationships are presented in terms of the percentage contributed to the variance in the original data. Also, it is noticeable that each component is more strongly correlated to some parameters that are considered most effective compared to others. The inter-correlation among the 13 basic, linear, and shape morphometric parameters related to the Zerqa River watershed are displayed in Table 5. A strong correlation (correlation coefficient $>0.9$ ) exists between elongation ratio $\left(\mathrm{R}_{\mathrm{e}}\right)$ and form factor $\left(\mathrm{R}_{\mathrm{f}}\right)$. Good correlations (correlation coefficient $>$ $0.75)$ exist between the elongation ratio $\left(\mathrm{R}_{\mathrm{e}}\right)$ and length of overland flow $\left(\mathrm{L}_{o}\right)$, form factor $\left(\mathrm{R}_{\mathrm{f}}\right)$ and length of overland flow $\left(\mathrm{L}_{\mathrm{o}}\right)$, stream frequency $\left(\mathrm{F}_{\mathrm{s}}\right)$ and drainage density $\left(D_{d}\right)$, bifurcation ratio $\left(R_{b}\right)$ and basin area $(A)$. Moderate correlations (correlation coefficient $>0.6$ ) also exist between compactness coefficient $\left(C_{c}\right)$ and shape factor $\left(B_{s}\right)$, length of overland flow $\left(L_{o}\right)$ and bifurcation ratio $\left(R_{b}\right)$, basin length $\left(\mathrm{L}_{b}\right)$ and basin area $(A)$, basin length $\left(\mathrm{L}_{b}\right)$ and perimeter $(\mathrm{P})$. Table 6 shows the component loading matrix. It is obvious that the first two components whose eigen-values are greater than 1 and together account for $90.6 \%$ of the total variance in the original data are significant. The rotated component matrix (Table 7) shows that component 1 is highly correlated with bifurcation ratio $\left(R_{b}\right)$, whereas component 2 is correlated satisfactorily with the shape factor $\left(B_{s}\right)$ and compactness coefficient $\left(\mathrm{C}_{c}\right)$. As indicated in (Table 7), the most important morphometric parameters are: shape factor $\left(\mathrm{B}_{\mathrm{s}}\right)$, bifurcation ratio $\left(\mathrm{R}_{\mathrm{b}}\right)$, and com- 
Table 5. Inter-correlation matrix of morphomrtric parameters of the Zerqa River watershed.

\begin{tabular}{|c|c|c|c|c|c|c|c|c|c|c|c|c|c|}
\hline $\begin{array}{l}\text { Morph. } \\
\text { Param. }\end{array}$ & A & $\mathrm{P}$ & $\mathrm{L}_{b}$ & $\mathrm{~L}_{\mathrm{u}}$ & $\mathrm{R}_{\mathrm{b}}$ & $D_{d}$ & $\mathrm{~F}_{\mathrm{s}}$ & $\mathrm{T}_{\mathrm{r}}$ & $\mathrm{L}_{o}$ & $\mathrm{R}_{\mathrm{f}}$ & $\mathrm{B}_{\mathrm{s}}$ & $\mathrm{R}_{\mathrm{e}}$ & $\mathrm{C}_{\mathrm{c}}$ \\
\hline A & 1.000 & & & & & & & & & & & & \\
\hline $\mathrm{P}$ & 0.710 & 1.000 & & & & & & & & & & & \\
\hline $\mathrm{L}_{\mathrm{b}}$ & 0.604 & 0.684 & 1.000 & & & & & & & & & & \\
\hline $\mathrm{L}_{\mathrm{u}}$ & 0.394 & 0.283 & 0.420 & 1.000 & & & & & & & & & \\
\hline $\mathrm{R}_{\mathrm{b}}$ & 0.837 & 0.649 & 0.448 & 0.441 & 1.000 & & & & & & & & \\
\hline $\mathrm{D}_{\mathrm{d}}$ & -0.578 & -0.365 & -0.476 & -0.101 & -0.287 & 1.000 & & & & & & & \\
\hline$F_{s}$ & -0.592 & -0.482 & -0.538 & -0.276 & -0.255 & 0.753 & 1.000 & & & & & & \\
\hline $\mathrm{T}_{\mathrm{r}}$ & -0.219 & -0.004 & -0.137 & 0.174 & -0.193 & 0.568 & -0.042 & 1.000 & & & & & \\
\hline $\mathrm{L}_{o}$ & 0.652 & 0.361 & -0.015 & 0.257 & 0.628 & -0.356 & -0.364 & -0.110 & 1.000 & & & & \\
\hline $\mathrm{R}_{\mathrm{f}}$ & 0.150 & 0.008 & -0.323 & 0.101 & 0.238 & -0.055 & -0.055 & -0.014 & 0.828 & 1.000 & & & \\
\hline $\mathrm{B}_{\mathrm{s}}$ & -0.160 & 0.235 & 0.578 & 0.091 & -0.170 & 0.061 & 0.061 & 0.007 & -0.512 & -0.423 & 1.000 & & \\
\hline $\mathrm{Re}_{\mathrm{e}}$ & 0.209 & -0.029 & -0.427 & 0.088 & 0.276 & -0.076 & -0.083 & -0.004 & 0.868 & 0.961 & -0.636 & 1.000 & \\
\hline $\mathrm{C}_{c}$ & -0.247 & 0.403 & 0.114 & -0.138 & -0.127 & 0.311 & 0.292 & 0.154 & -0.319 & -0.202 & 0.603 & -0.333 & 1.000 \\
\hline
\end{tabular}

Table 6. Total variance explained of Zerqa River watershed.

\begin{tabular}{|c|c|c|c|c|c|c|c|c|c|}
\hline \multirow[b]{2}{*}{ Component } & \multicolumn{3}{|c|}{ Initial Eigenvalues } & \multicolumn{3}{|c|}{ Extraction Sums of Squared Loadings } & \multicolumn{3}{|c|}{ Rotation Sums of Squared Loadings } \\
\hline & Total & $\begin{array}{c}\% \text { of } \\
\text { Variance }\end{array}$ & $\begin{array}{c}\text { Cumulative } \\
\%\end{array}$ & Total & $\begin{array}{c}\% \text { of } \\
\text { Variance }\end{array}$ & $\begin{array}{c}\text { Cumulative } \\
\%\end{array}$ & Total & $\begin{array}{c}\% \text { of } \\
\text { Variance }\end{array}$ & $\begin{array}{c}\text { Cumulative } \\
\%\end{array}$ \\
\hline 1 & 498.368 & 71.858 & 71.858 & 498.368 & 71.858 & 71.858 & 485.937 & 70.066 & 70.066 \\
\hline 2 & 129.980 & 18.741 & 90.600 & 129.980 & 18.741 & 90.600 & 142.411 & 20.534 & 90.600 \\
\hline 3 & 49.864 & 7.190 & 97.789 & & & & & & \\
\hline 4 & 6.671 & 0.962 & 98.751 & & & & & & \\
\hline 5 & 5.237 & 0.755 & 99.506 & & & & & & \\
\hline 6 & 1.799 & 0.259 & 99.766 & & & & & & \\
\hline 7 & 0.874 & 0.126 & 99.892 & & & & & & \\
\hline 8 & 0.443 & 0.064 & 99.956 & & & & & & \\
\hline 9 & 0.202 & 0.029 & 99.985 & & & & & & \\
\hline 10 & 0.067 & 0.010 & 99.994 & & & & & & \\
\hline
\end{tabular}

pactness coefficient $\left(\mathrm{C}_{\mathrm{c}}\right)$. Thus, these parameters are employed for prioritization of the 43 sub-watersheds of the Zerqa River. Table 8 illustrates the compound parameter $\left(C_{p}\right)$ values and the final priority ranks calculated based on the three morphometric parameters $\left(\mathrm{R}_{b}, \mathrm{~B}_{\mathrm{s}}\right.$, and $\left.\mathrm{C}_{\mathrm{s}}\right)$ elaborated by applying the PCA technique. On the basis of compound parameter $\left(C_{p}\right)$, values, sub-watersheds were grouped into high, moderate and low priority. Accordingly, nine sub-watersheds $5,20,21,2,38,40,41,42$, and 43 (20.9\% of the total sub-watersheds) fall under high priority (Figure 8), whereas, sub-watersheds 1, 3, 4, 7, 8, 9, 10, 14, 15, 16, 17, $18,19,22,24,30,36,37$, and $41(44.2 \%$ of the total sub-watersheds) are 
Table 7. Rotated component matrix.

\begin{tabular}{ccc}
\hline \multirow{2}{*}{ Morph. Param. } & \multicolumn{2}{c}{ Component } \\
\cline { 2 - 3 } A & 1 & 2 \\
\hline P & 0.905 & -0.288 \\
$\mathrm{~L}_{\mathrm{b}}$ & 0.940 & 0.282 \\
$\mathrm{~L}_{\mathrm{u}}$ & 0.681 & 0.480 \\
$\mathrm{R}_{\mathrm{b}}$ & 0.358 & 0.014 \\
$\mathrm{D}_{\mathrm{d}}$ & 0.794 & -0.251 \\
$\mathrm{~F}_{\mathrm{s}}$ & -0.500 & 0.152 \\
$\mathrm{~T}_{\mathrm{r}}$ & -0.582 & 0.102 \\
$\mathrm{~L}_{\mathrm{o}}$ & -0.099 & 0.110 \\
$\mathrm{R}_{\mathrm{f}}$ & 0.543 & -0.566 \\
$\mathrm{~B}_{\mathrm{s}}$ & 0.090 & -0.415 \\
$\mathrm{R}_{\mathrm{e}}$ & 0.023 & $\mathbf{0 . 9 5 3}$ \\
$\mathrm{C}_{\mathrm{c}}$ & 0.104 & -0.624 \\
\hline
\end{tabular}

Table 8. Final priority of the 43 sub-watersheds based on the PCA approach.

\begin{tabular}{|c|c|c|c|c|c|c|c|c|c|c|c|}
\hline Sub-watershed & $\mathbf{R}_{\mathrm{b}}$ & $\mathrm{B}_{s}$ & $\mathrm{C}_{\mathrm{c}}$ & $\begin{array}{l}\text { Compound } \\
\text { parameter } \\
\text { (Cp) }\end{array}$ & $\begin{array}{c}\text { Final } \\
\text { Priority }\end{array}$ & Sub-watershed & $\mathbf{R}_{\mathbf{b}}$ & $\mathbf{B}_{\mathrm{s}}$ & $\mathrm{C}_{\mathrm{c}}$ & $\begin{array}{l}\text { Compound } \\
\text { parameter } \\
\text { (Cp) }\end{array}$ & $\begin{array}{c}\text { Final } \\
\text { Priority }\end{array}$ \\
\hline 1 & 12 & 12 & 21 & 15 & 9 & 23 & 2 & 3 & 3 & 2.6 & 1 \\
\hline 2 & 30 & 43 & 10 & 27.6 & 25 & 24 & 5 & 32 & 33 & 23.3 & 19 \\
\hline 3 & 35 & 24 & 9 & 22.6 & 18 & 25 & 26 & 34 & 31 & 30.3 & 29 \\
\hline 4 & 20 & 25 & 18 & 21 & 16 & 26 & 16 & 41 & 39 & 32 & 30 \\
\hline 5 & 4 & 30 & 4 & 12.6 & 7 & 27 & 36 & 40 & 34 & 36.6 & 32 \\
\hline 6 & 21 & 14 & 15 & 16.6 & 12 & 28 & 42 & 33 & 37 & 37.3 & 33 \\
\hline 7 & 24 & 19 & 22 & 21.6 & 17 & 29 & 39 & 29 & 11 & 26.3 & 24 \\
\hline 8 & 18 & 22 & 32 & 24 & 21 & 30 & 6 & 28 & 19 & 17.6 & 13 \\
\hline 9 & 32 & 4 & 27 & 21 & 16 & 31 & 9 & 38 & 40 & 29 & 27 \\
\hline 10 & 31 & 7 & 16 & 18 & 17 & 32 & 34 & 42 & 41 & 39 & 34 \\
\hline 11 & 41 & 21 & 26 & 29.3 & 28 & 33 & 23 & 39 & 42 & 34.6 & 31 \\
\hline 12 & 38 & 26 & 17 & 27 & 25 & 34 & 25 & 31 & 35 & 30.3 & 29 \\
\hline 13 & 40 & 36 & 43 & 39.6 & 35 & 35 & 3 & 35 & 38 & 25.3 & 23 \\
\hline 14 & 19 & 27 & 28 & 24.6 & 22 & 36 & 37 & 20 & 14 & 23.6 & 20 \\
\hline 15 & 33 & 8 & 13 & 18 & 14 & 37 & 11 & 16 & 23 & 16.6 & 12 \\
\hline 16 & 27 & 18 & 8 & 17.6 & 13 & 38 & 7 & 1 & 12 & 6.6 & 2 \\
\hline 17 & 28 & 15 & 25 & 22.6 & 18 & 39 & 29 & 23 & 36 & 29.3 & 28 \\
\hline 18 & 43 & 5 & 7 & 16.6 & 12 & 40 & 10 & 10 & 20 & 13.3 & 8 \\
\hline 19 & 13 & 17 & 30 & 20 & 15 & 41 & 14 & 6 & 29 & 16.3 & 11 \\
\hline 20 & 22 & 9 & 6 & 12.3 & 6 & 42 & 17 & 11 & 2 & 10 & 4 \\
\hline 21 & 1 & 2 & 24 & 9 & 3 & 43 & 15 & 13 & 5 & 11 & 5 \\
\hline 22 & 8 & 37 & 1 & 15.3 & 10 & & & & & & \\
\hline
\end{tabular}




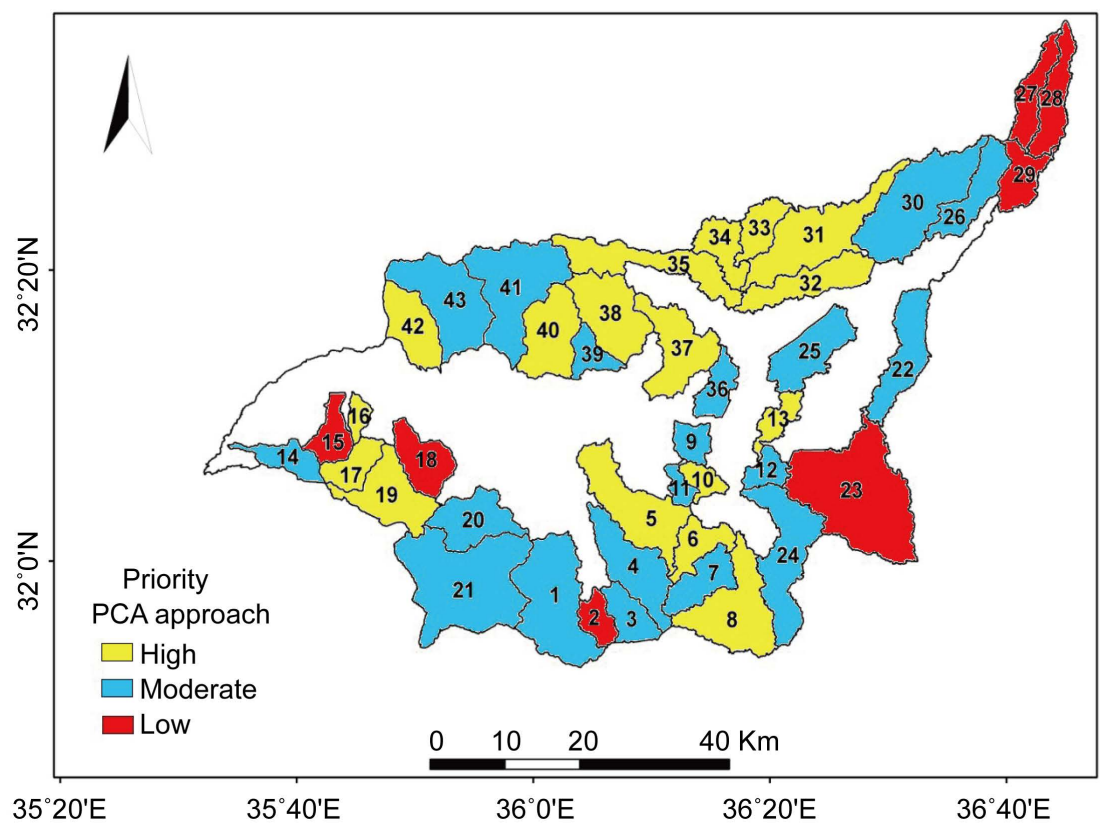

Figure 8. Priority of 43-sub-watersheds based on PCA analysis.

classified under moderate priority. Further, sub-watersheds $2,11,12,13,25,26$, $27,28,29,31,32,33,34,35$, and 39 (34.9\% of the total sub-watersheds) are categorized as low priority.

\subsection{Comparison of Sub-Watershed Prioritization Based on Morphometric Analysis and PCA Analysis}

Linear and shape parameters are employed to calculate the compound parameter $\left(C_{p}\right)$ for the Zerqa River sub-watersheds, and the final priority ratings for subwatersheds along with their placement in each prioritization category is illustrated in Table 4 . It is found that 17,19 , and 7 sub-watersheds are classified under high, moderate, and low priority respectively. Similarly, after applying the PCA analysis based on three parameters $\left(\mathrm{R}_{b}, \mathrm{~B}_{\mathrm{s}}\right.$, and $\left.\mathrm{C}_{c}\right)$ which are highly correlated with components 1 and 2 , the final prioritization and the associated priority category (high, moderate, and low)is illustrated in Table 8 . The final prioritization maps for the Zerqa River sub-watersheds are shown in Figure 7 and Figure 8. The prioritization of sub-watersheds based on morphometric and PCA analysis, were correlated to find out the common sub-watersheds falling under each priority. The correlation shows that 19 sub-watersheds ( $44.2 \%$ of the total) are common sub-watersheds in the priority falling under high, moderate, and low. Four sub-watersheds are classified under high level rank, eleven subwatersheds are categorized as of moderate priority, and four sub-watersheds are ranked with low priority (Table 9). Such results indicate that both prioritization methods employed did not produce similar results as stated recently by Gajbhiya and Sharma [48] in a study on the Shakkar River Catchment, Madhya Pradesh State, India. Such disagreement in the results related to the two case studies is mainly attributed to the differences in physical conditions between central India 
Table 9. Comparison of sub-watersheds for prioritization (morphometric and PCA approaches).

\begin{tabular}{|c|c|c|c|}
\hline \multirow{2}{*}{$\begin{array}{c}\text { Study } \\
\text { Approach }\end{array}$} & \multicolumn{2}{|c|}{ Priority Rank } & \multirow{2}{*}{ Low } \\
\hline & High & Moderate & \\
\hline $\begin{array}{l}\text { Morphometric } \\
\text { analysis }\end{array}$ & $\begin{array}{c}5,6,8,10,13,16,17,19, \\
31,32,33,34,35,37,38, \\
40,42\end{array}$ & $\begin{array}{c}1,3,4,7,9,11,12,14,20 \\
21,22,24,25,26,30,36 \\
39,41,43\end{array}$ & $2,15,18,23,27,28,29$ \\
\hline $\begin{array}{c}\text { PCA } \\
\text { analysis }\end{array}$ & $\begin{array}{c}5,20,21,23,38,40 \\
41,42,43\end{array}$ & $\begin{array}{c}1,3,4,7,8,9,10,14,15 \\
16,17,18,19,22,24,30 \\
36,37,41\end{array}$ & $\begin{array}{c}2,11,12,13,25,26,27 \\
28,29,31,32,33,34,35 \\
39\end{array}$ \\
\hline $\begin{array}{l}\text { Common Sub } \\
\text {-watersheds }\end{array}$ & 4 & 11 & 4 \\
\hline
\end{tabular}

*The bold figures represent the common sub-watersheds.

and northern Jordan. However, further comparative research must be carried out in different environments to verify the conclusion arrived by Gajbhiya and Sharma [48]. Thus, it is still more appropriate to conduct watershed prioritization research based on morphometric linear and shape parameters, and other approaches developed for this purpose, and to concentrate on elaborating the morphometric parameters employed.

\subsection{Proposed Soil and Water Conservation Measures}

Linear and shape parameters were employed to ascribe the priority of the 43 sub-watersheds. Information on land use/cover, soil type and slope has been utilized to help in proposing appropriate soil and water conservation measures. In the western part of the Zerqa River catchment, sub-watersheds nos. 5, 6, 8, 10, 13, $16,17,19,31,32,33,34,35,37,38$, and 40 are classified under high priority for soil conservation measures. These sub-watersheds represent typical rainfed areas which are subjected to intense rejuvenation, landslide activity, and severe soil erosion, past and present abuse of land resources, recurrent droughts, overgrazing, and expansion of settlements at the expense of the fertile agricultural lands. It is worth noting that farmers of rainfed cultivation are aware of the soil erosion problem and its prospective consequences. For example, $27 \%$ of the farmer' who lived across W. Kufranja (northern Jordan)and received a questionnaire designed to assess farmer' perception of soil erosion and conservation, believe that efficient land management is urgently needed to recover intensively exploited land resources [33]. Further, $40.8 \%$ of respondents were convinced that afforestation and tree plantation are crucial for reducing soil loss. Expected advantages of enhancing soil and water conservation measures over the highland, which accommodate considerable areas of rainfed cultivation, could be illustrated in the following: control of soil erosion in fragile terrain units, reduction in sediment load of the Jordan Rift wadis, and reduced peak flows across these wadis [92]. Reduction in soil erosion rates has been verified recently by Al-Alawi and Abujamous [93] who estimated the average annual soil loss in the salt district (central Jordan) at 78 ton $\cdot \mathrm{ha}^{-1} \cdot \mathrm{year}^{-1}$ before installation of soil conservation 
structures. Twenty years following this construction and tree-planting, the estimated average soil loss decreased considerably to an average of $33 \mathrm{ton} \cdot \mathrm{ha}^{-1} \cdot \mathrm{year}^{-1}$ (35.76\%). Moreover, it is postulated that in the years 1987-90, the estimated sediments yields were less than the actual ones in the KTD reservoir of the Zerqa River. This was attributed to the execution of a conservation practice program (Lower the Zerqa River watershed) conducted by the government of Jordan, in cooperation with the German government [12]. Such encouraging results emphasize the need to perform intensive research in order to reduce soil erosion loss, to improve the soil and water conservation techniques practiced, and to modify RUSLE parameters (i.e., C, P, and LS factors which are considered key factors in soil erosion). It has been stated that RUSLE parameters can be modified significantly through altering farmers environmental practices [94] with the support of local governments, where the farmers are aware of soil erosion problems. Cover and management factor $(\mathrm{C})$, conservation practice factor $(\mathrm{P})$, and slope length and steepness factor $\left(L_{s}\right)$ can be improved noticeably to reduce soil erosion loss, conserve water in soil at the farm, hillslope, or sub-watershed scale to maintain crop productivity. The LS factor can be modified by shortening the length and steepness of slopes through the construction of contour stone terraces (locally termed mastaba) accompanied by tree-planting on slope categories $0^{\circ}$ $-3^{\circ}, 3^{\circ}-15^{\circ}, 15^{\circ}-25^{\circ}$. Stone terraces should be placed in long rows along the contours at various intervals depending on length and steepness of slope [95]. Advantages of clearing the area from stones encourage the farmers to plow on contour. Grandoni terraces for forest trees and fruit trees could be implemented as well. In sub-watersheds where stones are not sufficiently available to build contour stone terraces, and where the land is too steep $\left(>25^{\circ}\right)$, bench terraces can be prepared. Terraced farming in the highlands of central and northern Jordan has been used extensively by farmers to reclaim hilly and sloping lands and to conserve soil and water in the farm. Such techniques have been adopted since the Nabatean period, some 3000 years ago [2]. The objective of these terraces is to minimize surface runoff, thereby increasing water infiltration in the soil. The installation of check dams, drop structures or, weir (i.e., concrete drop structure and chute, gabion structures) across the gullies ( $1-3 \mathrm{~m}$ of depth) and ravines $(>3 \mathrm{~m}$ in depth) can decrease runoff coefficients and soil erosion under various forms of land utilization [96]. Structural conservation measures can be applied on both gentle and steep slopes particularly across sub-watersheds falling under high priority, and with a high potential of possible soil and water degradation. Nevertheless, structural conservation measures should be integrated with technology enhancing farming practice (i.e., rotation and contour ploughing) of rainfed cultivation to reduce soil loss and improve crop productivity. Minimal vegetation cover dominates the steep and long slopes $\left(>20^{\circ}\right)$ along the major streams of these sub-watersheds. Steep slopes of $15^{\circ}-25^{\circ}$ category are cultivated, and tillage practices are performed up-and-down the slope instead of contour ploughing. Such practices accelerate soil erosion, and removal of the fertile surface layer, thus, degraded and non productive lands have increased. Irrespective 
of the installation of efficient conservation structures, improvement of cropping practice is fundamental in order to mitigate soil erosion on flat, gently sloping, moderately sloping or sloping rainfed farming areas. Contour strip intercropping cultivation at a proper planting density (i.e., 350 plants $\mathrm{m}^{-2}$ ) was found to be a promising farming practice to reduce runoff and soil erosion [97]. Similarly, experimental results on soil erosion control and moisture conservation, revealed that the presence of rock fragments on the surface were highly effective in reducing runoff and soil loss. Traditionally, farmers tend to clear land surface of stone and rock fragments which should not be the case, at a certain level of surface coverage (i.e., $5 \%$ - 15\%) [95]. Sub-watersheds nos. 9, 12, 21, 24, 25, 36, and 39 as an example are categorized as of moderate priority for soil conservation measures. All these sub-watersheds occupied semi-arid rangeland, and marginal cultivation, where the average annual rainfall is $200 \mathrm{~mm}$ approximately. These marginal areas are termed locally "tenth land", i.e., producing crops every ten years because of low rainfall. Continuous cultivation of marginal lands accelerates soil erosion. Furthermore, ploughing these areas has eradicated the natural grasses, thus making them unsuitable for grazing. Overgrazing together with recurrent drought, has gradually damaged the grazing capacity of the land. Consequently, the protection of present vegetation cover, and redeveloping of the natural vegetation by means of seeding selected areas/sub-watersheds with appropriate grasses, and planning for efficient rangeland management [98]. Expanding tree-planting of drought-resistance species is also recommended. Subwatersheds nos. 23, 27, 28 and 29 are examples of low priority sub-watersheds for soil conservation measures. Most of the land surface here is covered by basaltic boulders, cobbles, and basalt rock fragments of different sizes, depending on the rate of weathering and the geological age of basalt. These lands constitute poor rangeland. Field experiments under natural rainfall conditions revealed that the presence of cobbles, stone and rock fragments in the field decreases runoff and soil loss from the field and increases infiltration and natural vegetation cover [95]. Application of stone at 5\% and 15\% surface coverage caused reasonable reduction in runoff by an average of $17 \%$ and $30 \%$ respectively. Moreover, the corresponding reductions in soil loss for both stone treatments were as large as $35 \%$ and $53 \%$ respectively. Growth of trees also is found to be better with a reasonable stone coverage due to the increase of infiltration and decrease in soil loss. The optimal utilization for these sub-watersheds is to rehabilitate the vegetation cover as a first step toward improving grazing potential.

\section{Conclusion}

Land degradation caused by severe soil erosion loss has seriously threatened the rainfed agriculture over the highland watersheds in central and northern Jordan including the Zerqa River catchment. Soil erosion has also increased sediment yield in the wadis/rivers particularly during heavy rainstorms. Hence, prioritization of the 43 sub-watersheds is crucial, and emphasizes the need to institute appropriate soil conservation measures, in order to maintain future farming 
sustainability. In the present investigation, integrated remote sensing, GIS, mophometric analysis, and principal component Analysis (PCA) techniques were employed to prioritize the sub-watersheds, and then to recommend efficient conservation measures. The prioritized sub-watersheds are located in three different bio-climatic zones which are varied in terms of physical conditions. These are: the rainfed agricultural areas; the rangelands, and poor grazing areas which are partially covered with basalt boulders and cobbles. Prioritization of subwatersheds was performed through analyzing ten linear and shape morphometric parameters related to the 43 sub-watersheds, and Principal Component Analysis. Then all sub-watersheds were assigned a rank on the basis of priority for adopting appropriate soil conservation measures. Additionally, supplementary information on land use, slope, and soil types was utilized to help in proposing proper soil and water conservation structures particularly for sub-watersheds as being categorized under high priority, and highly vulnerable to soil erosion loss. Appropriate soil conservation measures are suggested, taking into consideration land use/land cover in each sub-watershed, i.e., rainfed agriculture, limited irrigated farming, rangeland, soils, bare ground covered partially with basalt boulders and cobbles, and slopes which vary between 0 and $25^{\circ}$. Relevant soil conservation measures were proposed in accordance to priority ascribed in order to minimize the adverse effect on land and environment. Furthermore, the priority assigned for the sub-watersheds was evaluated with reference to morphometric properties, predominant environmental conditions, and Principal Component Analysis (PCA). The results of prioritization based on morphometric analysis indicate that sub-watershed no. 35 has been ranked 1 with lowest compound parameters $\left(\mathrm{C}_{\mathrm{p}}\right)$ at 14.3 , while sub-watershed no. 31 and no. 8 are ranked as the second and third, with compound parameters at 17.0 and respectively, and with a high priority (Figure 7, and Table 4). Further, subwatersheds no. 40 and no. 33 are ranked as the fourth and fifth with compound parameters at 18.4, and 18.9 and with high priority as well. By contrast, subwatersheds no. 1 , no. 20 , and no. 30 are ranked as 26,16 and 17 with compound parameters at 23.9, 21.5, and 21.6 respectively, and with moderate priority. Additionally, sub-watersheds no. 27 , no. 28 , and no. 29 are ranked as 32,34 and 35 , with compound parameters at 27.0, 27.5, and 27.8 respectively, and with low priority. However, a more regional approach can be elaborated and employed to establish satisfying data base/information using the methodology adopted here (or combined with other approaches, i.e., sediment yield, land use/cover, and soil loss modeling) to attain an optimum threshold for prioritization of rejuvenated watersheds suffering from high soil erosion rates, and deterioration of natural vegetation. The study demonstrates that the priority registry demarcates sub-watershed of noticeable land and water degradation, and thus of high "potential" for application of immediate conservation measures. These results are expected also to assist decision-makers in identifying priority sub-watersheds which need instant adaptation of proper conservation and land management practices. This investigation also verifies the efficiency of remote sensing and 
GIS techniques in prioritization of the Zerqa River sub-watersheds, and proves the capacity of morphometric parameters (computation and analysis) in prioritization research within GIS platform, for the Zerqa River and other comparable watersheds in central and northern Jordan.

\section{References}

[1] Christopherson, G. and Guertin, D. (1995) Soil Erosion, Agricultural Intensification, and Iron Age Settlement in the Region of Tall el-Umeiri. Unpublished Paper Presented at the Annual Meeting of the American Schools of Oriental Research, Philadelphia.

[2] Cordova, C.E. (2000) Geomorphological Evidence of Intense Prehistoric Soil Erosion in the Highlands of Central Jordan. Physical Geography, 21, 538-567.

[3] Jebari, S., Berndtsson, R., Labdi, F. and Bahri, A. (2012) Historical Aspects of Soil Erosion in the Mejerda Catchment, Tunisia. Hydrological Sciences Journal, 57, $901-$ 912. https://doi.org/10.1080/02626667.2012.685741

[4] Mcdonald Partners and Hunting Technical Services LTD (1965) East Bank Water Resources Summary Report. Central Water Authority, Amman.

[5] Central Water Authority (1966) Hydrological Division. Floods in Southern Jordan on 11 March 1966, Amman, Jordan.

[6] Schick, A. (1971) A Desert Flood: Physical Characteristics, Effect on Man Geomorphic Significance, Human Adaptation-A Case Study in the Southern Arava Watershed. Jerusalem Studies in Geography, 2, 91-155.

[7] Farhan, Y. (1986) Landslides in Central Jordan with Special Reference to the March 1983 Rainstorm. Singapore Journal of Tropical Geography, 7, 80-96.

https://doi.org/10.1111/j.1467-9493.1986.tb00174.x

[8] Farhan, Y. (1999) Geomorphic Impacts of Highway Construction, Their Causes and Remedies: A Case Study from Aqaba, Southern Jordan. Arab World Geographer, 2, $1-25$.

[9] Farhan, Y. (2002) Slope Stability Problems in Central and Northern Jordan. Arab World Geographer, 5, 265-290.

[10] Harza (1980) Report on Dam Heightening. Jordan Valley Authority, Amman.

[11] Lara, J.M. (1980) The 1980 Sedimentation Survey of King Talal Dam. Jordan Valley Authority, Amman, Jordan.

[12] Al-Sheriadeh, M.S. and Al-Hamdan, A.Z. (1999) Erosion Risk Assessment and Sediment Yield Production of King Talal Watershed, Jordan. Environmental Geology, 37, 234-242. https://doi.org/10.1007/s002540050381

[13] Al-Sherideh, M.S., Malkawi, A., Al-Hamdan, H. and Abdulrahman, N. (2000) Evaluating Sediment Yield at King Talal Reservoir from Landslides along Irbid-Amman Highway. Engineering Geology, 56, 361-372. https://doi.org/10.1016/S0013-7952(99)00119-2

[14] Al-Ansari, N. and Knutsson, S. (2010) Reduction of the Storage Capacity of Two Small Reservoirs in Jordan. Journal of Earth Science and Geotechnical Engineering, 2, 13-37.

[15] Farhan, Y., Zerqat, D. and Farhan, I. (2013) Spatial Estimation of Soil Erosion Risk Using RUSLE Approach, RS, and GIS Techniques: A Case Study of Kufranja Watershed, Northern Jordan. Journal of Water Resources and Protection, 5, 1247-1261. https://doi.org/10.4236/jwarp.2013.512134 
[16] Farhan, Y. and Nawaiseh, S. (2015) Spatial Assessment of Soil Erosion Risk Using RUSLE and GIS Techniques. Environmental Earth Sciences, 74, 4649-4669. https://doi.org/10.1007/s12665-015-4430-7

[17] Ministry of Water and Irrigation, Jordan (2010) Final Design of the Construction of Kufranja Dam. Energoprojekt, Belgrade.

[18] Ministry of Water and Irrigation, Jordan (2011) Final Design Report of Kerak Dam. Engicon, Amman.

[19] Ijam, A. and Tarawneh, E. (2012) Assessing of Sediment Yield for Wala Dam Catchment Area in Jordan. European Water, 38, 43-58.

[20] Ijam, A. and Al-Mahamid, M. (2012) Predicting Sedimentation at Mujib Dam Reservoir in Jordan. Jordan Journal of Civil Engineering, 6, 448-463.

[21] Morgan, R. (1977a) Soil Erosion: Topics in Applied Geography. Longman, London.

[22] Morgan, R. (1977b) Soil Erosion in the United Kingdom: Field Studies in the Silsoe Area 1973-1975. Occasional Paper No. 4 National College of Agricultural Engineering, London.

[23] Dabbas, I. (1994) Soil Erosion Measurements in the Salt Area, Jordan. M.A. Thesis, University of Jordan. Amman. (In Arabic)

[24] Ananzeh, A. (1986) Sediment Yield of Wadi Kufranja Basin. M.A. Thesis, University of Jordan, Amman. (In Arabic)

[25] Beni Taha, Q. (2004) Soil Erosion in Jerash Area. M.A. Thesis, University of Jordan, Amman. (In Arabic)

[26] Jawabreh, A. (1995) Soil Erosion Measurements in the Muwaqar Area, Jordan. M.A. Thesis, University of Jordan, Amman. (In Arabic)

[27] Al-Hamdan, A. (1996) Soil Erosion Measurements in the Azraq Area, Jordan. M.A. Thesis, University of Jordan, Amman. (In Arabic)

[28] Al-Shabatat, A. (2005) Environmental Deterioration and Land Management in the Petra-Showbak Area, Jordan. Ph.D. Dissertation. University of Jordan, Amman. (In Arabic)

[29] Beaumont, P. and Atkinson, K. (1969) Soil Erosion and Conservation in Northern Jordan. Journal of Soil and Water Conservation, 24, 144-147.

[30] Willimott, S.G., Birch, B.P., Mckee, R.F., Atkinson, K. and Nimry, B.S. (1964) Conservation Survey of the Southern Highlands of Jordan. Unpublished Report, Department of Geography, University of Durham, Durham.

[31] Willimott, S.G., Gilchrist-Shirlaw, D.G., Smith, R.A. and Birch, B.P. (1963) The Wadi Hasa Survey, Jordan. Unpublished Report, Department of Geography, University of Durham, Durham.

[32] Atkinson, K., Beaumont, P., Bowen-Jones, H., Fisher, W.B. and Gilchrist-Shirlaw, D.W. (1967) Soil Conservation Survey of Wadi Shueib and Wadi Kufrein, Jordan. Unpublished Report, Department of Geography, University of Durham, Durham.

[33] Farhan, Y., Zreqat, D. and Anbar, A. (2015) Assessing Farmers' Perception of Soil Erosion Risk in Northern Jordan. Journal of Environmental Protection, 6, 867-884. https://doi.org/10.4236/jep.2015.68079

[34] Biswas, S., Sudhakar, S. and Desai, V.R. (1999) Prioritization of Sub-Watersheds Based on Morphometric Analysis of Drainage Basin: A Remote Sensing and GIS Approach. Journal of the Indian Society of Remote Sensing, 27, 155-166. https://doi.org/10.1007/BF02991569

[35] Javed, A., Khanday, M.A. and Ahmad, R. (2009) Prioritization of Sub-Watersheds Based on Morphometric and Land Use Analysis in Guna District (M.P.): A Remote 
Sensing and GIS Approach. Journal of the Indian Society of Remote Sensing, 37, 261-274. https://doi.org/10.1007/s12524-009-0016-8

[36] Javed, A., Khanday, M.A. and Rias, S. (2011) Watershed Prioritization Using Morphometric and Land Use/Land Cover Parameters: A Remote Sensing and GIS Approach. Journal Geological Society of India, 78, 63-75.

https://doi.org/10.1007/s12594-011-0068-6

[37] Patel, D., Dholakia, M., Naresh, N. and Srivastava, P. (2012) Water Harvesting Structure Positioning by Using Geo-Visualization Concept and Prioritization of Mini-Watersheds through Morphometric Analysis in the Lower Tapi Basin. Journal of the Indian Society of Remote Sensing, 40, 299-312. https://doi.org/10.1007/s12524-011-0147-6

[38] Patel, D., Gajjar, C. and Srivastava, P. (2013) Prioritization of Malesari Mini-Watersheds through Morphometric Analysis: A Remote Sensing and GIS Perspective. Environmental Earth Sciences, 69, 2643-2656. https://doi.org/10.1007/s12665-012-2086-0

[39] Gajbhiya, S., Mishra, S.K. and Pandey, A. (2014) Prioritizing Prone-Area through Morphometric Analysis: An RS and GIS Perspective. Applied Water Science, 4, 51-56. https://doi.org/10.1007/s13201-013-0129-7

[40] Abdul Rahaman, S., Abdul Ajeez, S., Aruchamy, S. and Jegankumar, R. (2015) Prioritization of Sub Watersheds Based on Morphometric Characteristics Using Fuzzy Analytical Hierarchy Process and Geographical Information System-A Study of Kallar Watershed, Tamil Nadu. Aquatic Procedia, 4, 1322-1330. https://doi.org/10.1016/j.aqpro.2015.02.172

[41] Kubit, O.E., Pluhar, C.J. and De Graff, J.V. (2015) A Model for Prioritizing Site and Reclamation Methods at Abandoned Mines. Environmental Earth Sciences, 73, 7915-7931. https://doi.org/10.1007/s12665-014-3949-3

[42] Khanday, M.Y. and Javed, A. (2016) Prioritization of Sub-Watersheds for Conservation Measures in a Semi Arid Watershed Using Remote Sensing and GIS. Journal Geological Society of India, 88, 185-196. https://doi.org/10.1007/s12594-016-0477-7

[43] Makwara, J. and Tiwari, M. (2016) Prioritization of Agricultural Watersheds in Semi Arid Middle Region of Gujarat Using Remote Sensing and GIS. Environmental Earth Sciences, 75, 137-159. https://doi.org/10.1007/s12665-015-4935-0

[44] Gopinath, G., Nair, A.G., Ambili, G.K. and Swetha, T.V. (2016) Watershed Prioritization Based on Morphometric Analysis Coupled With Multi Criteria Decision Making. Arab Journal of Geosciences, 9, 129-146.

https://doi.org/10.1007/s12517-015-2238-0

[45] Fallah, M., Kavian, A. and Omidver, E. (2016) Watershed Prioritization in Order to Implement Soil and Water Conservation Practices. Environmental Earth Sciences, 75, 1248-1265. https://doi.org/10.1007/s12665-016-6035-1

[46] Nooka Ratnam, K., Srivastava, Y.K., Venkateshwara Rao, V. Amminedu, E. and Murthy, K.S.R. (2005) Check Dam Positioning and Prioritization of Micro-Watersheds Using SYI Model and Morphometric Analysis-Remote Sensing and GIS Perspective. Journal of the Indian Society of Remote Sensing, 33, 25-38. https://doi.org/10.1007/BF02989988

[47] Patel, D.P. and Dholakia, M. (2010) Feasible Structural and Non-Structural Measures to Minimize Effect of Flood in Lower Tapi Basin. International Journal WSEAS Transactions of Fluid Mechanics, 3, 104-121.

[48] Gajbhiye, S.M. and Sharma, S.K. (2015) Prioritization of Watersheds through Morphometric Parameters: A PCA Approach. Applied Water Science (Springer). 
[49] Sureh, M., Sudhakar, S., Tiwari, K.N. and Chowdacy, V.M. (2004) Prioritization of Watersheds Using Morphometric Parameters and Assessment of Surface Water Potential Using Remote Sensing. Journal of the Indian Society of Remote Sensing, 32, 249-259. https://doi.org/10.1007/BF03030885

[50] Chaudhary, R.S. and Sharma, P.D. (1998) Erosion Hazard Assessment and Treatment Prioritization of Giri River Catchment, North Western Himalayas. Indian Journal of Soil Conservation, 26, 6-11.

[51] Singh, N. and Singh, K.K. (2014) Geomorphological Analysis and prioritization of Sub-Watersheds Using Snyder's Unit Hydrograph Method. Applied Water Science (Springer).

[52] Van Zuidam, R. and Van Zuidam, C. (1979) Terrain Analysis and Classification Using Aerial Photographs: A Geomorphological Approach. ITC, Enschede.

[53] Jaiswal, R., Thomas, T., Galkate, R., Ghosh, N. and Singh, S. (2014) Watershed Prioritization Using Saaty's AHP Based Decision Support for Soil Conservation Measures. Water Resources Management, 28, 475-494.

https://doi.org/10.1007/s11269-013-0494-x

[54] Horton, R. (1945) Erosional Development of Streams and their Drainage Basins: Hydrological Approach to Quantitative Morphology. Geological Society of America Bulletin, 56, 275-370. https://doi.org/10.1130/0016-7606(1945)56[275:EDOSAT]2.0.CO;2

[55] Strahler, A.N. (1957) Quantitative Analysis of Watershed Geomorphology. Transactions, American Geophysical Union, 38, 913-920. https://doi.org/10.1029/TR038i006p00913

[56] Strahler, A.N. (1964) Quantitative Geomorphology of Drainage Basins and Channel Network. In: Chow, V., Ed., Handbook of Applied Hydrology, McGraw-Hill, New York, 439-476.

[57] Miller, V. (1953) A Quantitative Geomorphic Study of Drainage Basin Characteristics in the Clinch Mountain Area, Virginia and Tennessee. Project NR 389-402, Technical Report 3, Columbia University, Department of Geology, ONR, New York.

[58] Schumm, S. (1956) Evolution of Drainage Systems and Slopes in Badlands at Perth Amboy, New Jersey. Geological Society of America Bulletin, 67, 464-597. https://doi.org/10.1130/0016-7606(1956)67[597:EODSAS]2.0.CO;2

[59] Gajbhiye, S., Mishra, S.K. and Pandey, A. (2014) Prioritizing Erosion-Prone Area Through Morphometric Analysis: An RS and GIS Perspective. Applied Water Science, 4, 51-61. https://doi.org/10.1007/s13201-013-0129-7

[60] Magesh, N.S., Jitheshlarl, K.V. and Chandrasekar, N. (2013) Geographical Information System-Based Morphometric Analysis of Bharathapuzha River Basin, Kerala, India. Applied Water Science, 3, 467-477. https://doi.org/10.1007/s13201-013-0095-0

[61] Bender, F. (1974) Geology of Jordan. Khdeir, M.K., Trans., Beiträge zur regionalen Geologie der Erde, Vol. 7, Gebrüder, Borntraeger, Berlin.

[62] Bender, F. (1975) Geology of the Arabian Peninsula: Jordan. United States Geological Survey Professional Paper 560-I, Washington DC.

[63] Abed, A. (1982) Geology of Jordan, Amman (In Arabic).

[64] Salameh, E. (1980) Hydrogeology and Hydrochemistry in the Catchment Area of the King Talal Reservoir, Jordan. Zeitschrift der Deutschen Geologischen Gesellschaft, 131, 319-338.

[65] Quennell, A. (1958) The Structure and Geomorphic Evolution of the Dead Sea Rift. 
Quarterly Journal of the Geological Society, 114, 1-24.

https://doi.org/10.1144/gsigs.114.1.0001

[66] Burdon, D. (1959) Handbook of the Geology of Jordan. Benham and Co., Colchester.

[67] Mickbel, Sh. and Zacher, W. (1981) The Wadi Shueib Structure in Jordan. Neues Jahrbuch für Geologie und Paläontologie Monatshefte, 9, 571-576.

[68] Mickbel, Sh. and Zacher, W. (1986) folded Structure in Northern Jordan. Neues Jahrbuch für Geologie und Paläontologie Monatshefte, 14, 248-256.

[69] Atallah, N. and Mickbel, Sh. (1983) Geology and Structure of an Area East of the Dead Sea. Proceedings of the $1^{\text {st }}$ Geological Conference, Amman, 6-8 September 1983, 392-414.

[70] Farhan, Y. (1986) Landslide in Central Jordan with Special Reference to the March 1983 Rainstorm. Singapore Journal of Tropical Geography, 7, 80-97.

https://doi.org/10.1111/j.1467-9493.1986.tb00174.x

[71] Fisher, W.H., Bowen-Jones, H., Atkinson, K., Beaumont, P., Smith, K. and Stevens, J. (1969) Soil and Land Potential Survey of the Highlands of North-West Jordan. Unpublished Report, University of Durham, Durham.

[72] Farhan, Y. (1985) Geomorphological Mapping of Landslides Complex Area in a Part of the Zerqa River, Central Jordan. Annales de Geographie, 6, 31-39.

[73] Anderson, J., Hardy, E., Roach, J. and Witmer, R. (1976) A Land Use and Land Cover Classification System for Use with Remote Sensory Data. US Geological Survey Professional Paper 964, Washington DC.

[74] Ministry of Agriculture, Jordan (1995) The Soils of Jordan. Report of the National Soil Map and Land Use Project. Ministry of Agriculture, Hunting Technical Services LTd and European Commission, Amman.

[75] Gravelius, H. (1914) Grundriß der gesamten Gewässerkunde, Band 1: Flußkunde. Compendium of Hydrology, I, 265-278.

[76] Scheidegger, A.E. (1970) Theoretical Geomorphology. George Allen and Unwin, London. https://doi.org/10.1007/978-3-662-01025-9

[77] Yang, M. and Lee, K. (2001) Determination of Probability Distributions for Strahler Stream Lengths Based on Poisson Process and DEM. Hydrological Science Journal, 46, 813-824. https://doi.org/10.1080/02626660109492872

[78] Al-Saady, Y.I., Al-Suhail, Q.A., Al-Tawash, B.S. and Othman, A. (2016) Drainage network Extraction and Morphometric Analysis Remote Sensing and GIS Mapping Techniques (Lesser Zab River Basin, Iraq and Iran). Environmental Earth Sciences, 75, 1243-1266. https://doi.org/10.1007/s12665-016-6038-y

[79] Kanth, T. and Hassan, Z. (2012) Morphometric Analysis and Prioritization of Watersheds for Soil and Water Resources Management in Water Catchment Using Geo-Spatial Tools. International Journal of Geology, Earth and Environmental Sciences, 2, 30-41.

[80] Prasad, R.K., Mondal, N.C., Banerjee, P., Nandakumar, N.V. and Singh, V.S. (2008) Deciphering Potential Groundwater Zone in Hard Rock through the Application of GIS. Environmental Geology, 55, 467-475. https://doi.org/10.1007/s00254-007-0992-3

[81] Deju, R. (1971) Regional Hydrology Fundamentals. Gordon and Breach Science Publishers, New York.

[82] Altaf, F., Meraj, G. and Romshoo, S.A. (2013) Morphometric Analysis to Infer Hydrological Behavior of Lidder Watershed, Western Himalaya, India. Geography 
Journal, 13, 1-14. https://doi.org/10.1155/2013/178021

[83] Tuker, G.E. and Bras, R.L. (1998) Hillslope Processes, Drainage Density, and Landscape Morphology. Water Resources Research, 34, 2751-2764. https://doi.org/10.1029/98WR01474

[84] Lykoudi, E. and Angelaki, M. (2004) Contribution to the Morphometry Parameters of an Hydrographic Network to the Investigation of the Neotechtonic Activity: An Application to the Upper A Cheloos River, Bulletin of Greek Geological Society, 36, 1084-1092.

[85] Zavoianu, I. (1985) Morphometry of Drainage Basins (Developments in Water Science). Elsevier, Amsterdam.

[86] Varade, A.M., Khare, Y.D., Mondal, N.C., Muley, S., Wankawar, P. and Raut, P. (2013) Identification of Water Conservation Sites in a Watershed (WRJ-2) of Nagpur District, Maharashtra Using Geographical Information System (GIS) Techniques. Journal of the Indian Society of Remote Sensing, 41, 619-630. https://doi.org/10.1007/s12524-012-0232-5

[87] Umrikar, B. (2015) GIS Techniques in Management of Watershed Developed Along the Korkan Coast, Maharashtra, India. Journal of Geographic Information System, 7, 280-293. https://doi.org/10.4236/igis.2015.73022

[88] Nearing, M.A., Ascough, L.D. and Laften, J.M. (1990) Sensitivity Analysis of the WEPP Hillslope Profile Erosion Model. Transactions, ASAE, 33, 839-849. https://doi.org/10.13031/2013.31409

[89] Irvem, A., Topaloglu, F. and Uyagur, V. (2007) Estimating Spatial Distribution of Soil Loss over Seyhan River Basin in Turkey. Journal of Hydrology, 336, 30-37. https://doi.org/10.1016/j.jhydrol.2006.12.009

[90] Trabucchi, M., Puente, C., Comin, F., Olague, G. and Smith, S. (2012) Mapping Erosion Risk at the Basin Scale of the Mediterranean Environment with Opencast Coal Mines to Target Restoration Actions. Regional Environmental Change, 12, 675-687. https://doi.org/10.1007/s10113-012-0278-5

[91] Mather, P. and Doornkamp, J.C. (1970) Multivariate Analysis in Geography with Particular Reference to Drainage-Basin Morphometry. Transactions of the Institute of British Geographers, 51, 163-187. https://doi.org/10.2307/621768

[92] El-Swaify, S. and Hurni, H. (1996) Transboundary Effects of Soil Erosion and Conservation in the Nile Basin. Land Husbandry, 1, 7-210.

[93] Al-Alawi, M. Abujamous, M. (2009) Estimation of Soil Erosion in Jordan by Using GIS. In: De Amicis, R., et al., Eds., Geospatial Visual Analytics: Geographical Information Processing and Visual Analytics for Environmental Security, Springer, Berlin, 439-450. https://doi.org/10.1007/978-90-481-2899-0 35

[94] Mhangara, P., Kakembo, V. and Lim, K.J. (2012) Soil Erosion Risk Assessment of the Keiskamma Catchment, South Africa Using GIS and Remote Sensing. Environmental Earth Sciences, 65, 2087-2092.

https://doi.org/10.1007/s12665-011-1190-x

[95] Abu-Zreig, M.M., Tamimi, A. and Alazba, A.A. (2011) Soil Erosion Control and Moisture Conservation in Arid Lands with Stone Cover. Arid Land Research and Management, 25, 294-307. https://doi.org/10.1080/15324982.2011.565859

[96] Rozos, D., Skilodimou, H.D., Loupasakis, C. and Bathrellos, G.D. (2013) Application of the Revised Universal Soil Loss Equation Model on Landslide Prevention. An Example from N. Euboea (Evia) Island, Greece. Environmental Earth Sciences, 70, 3255-3266. https://doi.org/10.1007/s12665-013-2390-3

[97] Sharaiha, R. and Ziadat, F. (2007) Alternative Cropping Systems to Control Soil 
Erosion in Arid to Semi-Arid Areas of Jordan. African Crop Science Conference Proceedings, 8, 1559-1565.

[98] Shammout, S. (1980) The Jordanian Experience in Rainfed Agriculture, Paper Submitted to the Rainfed Agriculture in the Near East and North Africa Meeting, FAO, Rome.

Submit or recommend next manuscript to SCIRP and we will provide best service for you:

Accepting pre-submission inquiries through Email, Facebook, LinkedIn, Twitter, etc. A wide selection of journals (inclusive of 9 subjects, more than 200 journals)

Providing 24-hour high-quality service

User-friendly online submission system

Fair and swift peer-review system

Efficient typesetting and proofreading procedure

Display of the result of downloads and visits, as well as the number of cited articles

Maximum dissemination of your research work

Submit your manuscript at: http://papersubmission.scirp.org/

Orcontact as@scirp.org 